\title{
Targeting the Epidermal Growth Factor Receptor in Epithelial Ovarian Cancer: Current Knowledge and Future Challenges
}

\author{
Doris R. Siwak, ${ }^{1}$ Mark Carey, ${ }^{1}$ Bryan T. Hennessy, ${ }^{2}$ Catherine T. Nguyen, ${ }^{1}$ \\ Mollianne J. McGahren Murray, ${ }^{1}$ Laura Nolden, ${ }^{1}$ and Gordon B. Mills ${ }^{1}$
${ }^{1}$ Department of Systems Biology, The University of Texas M. D. Anderson Cancer Center, 1515 Holcombe Boulevard, Houston, TX 77030, USA
${ }^{2}$ Department of Gynecologic Medical Oncology, The University of Texas M. D. Anderson Cancer Center, 1515 Holcombe Boulevard, Houston, TX 77030, USA

Correspondence should be addressed to Doris R. Siwak, dsiwak@mdanderson.org

Received 1 May 2009; Accepted 31 August 2009

Academic Editor: Maurie M. Markman

Copyright (c) 2010 Doris R. Siwak et al. This is an open access article distributed under the Creative Commons Attribution License, which permits unrestricted use, distribution, and reproduction in any medium, provided the original work is properly cited.

\begin{abstract}
The epidermal growth factor receptor is overexpressed in up to $60 \%$ of ovarian epithelial malignancies. EGFR regulates complex cellular events due to the large number of ligands, dimerization partners, and diverse signaling pathways engaged. In ovarian cancer, EGFR activation is associated with increased malignant tumor phenotype and poorer patient outcome. However, unlike some other EGFR-positive solid tumors, treatment of ovarian tumors with anti-EGFR agents has induced minimal response. While the amount of information regarding EGFR-mediated signaling is considerable, current data provides little insight for the lack of efficacy of anti-EGFR agents in ovarian cancer. More comprehensive, systematic, and well-defined approaches are needed to dissect the roles that EGFR plays in the complex signaling processes in ovarian cancer as well as to identify biomarkers that can accurately predict sensitivity toward EGFR-targeted therapeutic agents. This new knowledge could facilitate the development of rational combinatorial therapies to sensitize tumor cells toward EGFR-targeted therapies.
\end{abstract}

\section{Introduction}

Epithelial ovarian cancer, defined as cancers arising either from the mesothelial lining of the ovaries (either from the epithelial surface lining or cortical ovarian cysts formed by invaginations of the surface epithelium) or from the fallopian tube epithelium [1], accounts for $90 \%$ of ovarian malignancies [2]. Epithelial ovarian cancers are further divided into 5 histologic subtypes: serous, endometrioid, mucinous, clear cell, and undifferentiated. Aberrant epidermal growth factor receptor (EGFR) expression is detected in up to $60 \%$ of ovarian cancers and occurs in all histologic subtypes $[3,4]$. Further, aberrant EGFR expression is associated with poor outcome of ovarian cancer patients $[5,6]$. In this article, we review the EGFR family, the role of EGFR in ovarian cancer, and the methods used to determine this role. We also summarize the results of anti-EGFR therapies in ovarian cancer clinical trials and discuss challenges and future work in effective treatments utilizing anti-EGFR therapies in ovarian cancer, focusing on epithelial ovarian cancer whenever possible.

1.1. The Epidermal Growth Factor Receptor Family. The EGFR family (also known as the HER or ERBB family) consists of 4 members: EGFR, HER2, HER3, and HER4 (alternately known as ERBB1-4). Structurally, the EGFR family consists of an extracellular ligand binding domain, a single transmembrane-spanning region, and an intracellular region containing the kinase domain (Figure 1; reviewed in [7-10]). In humans, more than 30 ligands have been identified that bind to the EGFR family, including EGF and EGF-like ligands, transforming growth factor (TGF)- $\alpha$, and heregulins (HRGs, also known as neuregulins) [11].

EGFR is activated upon ligand binding, which results in a conformational change in the extracellular domain, leading to homo- or heterodimerization with another EGFR family member. The EGFR binding partner appears to depend on several properties, including the proportion of EGFR 


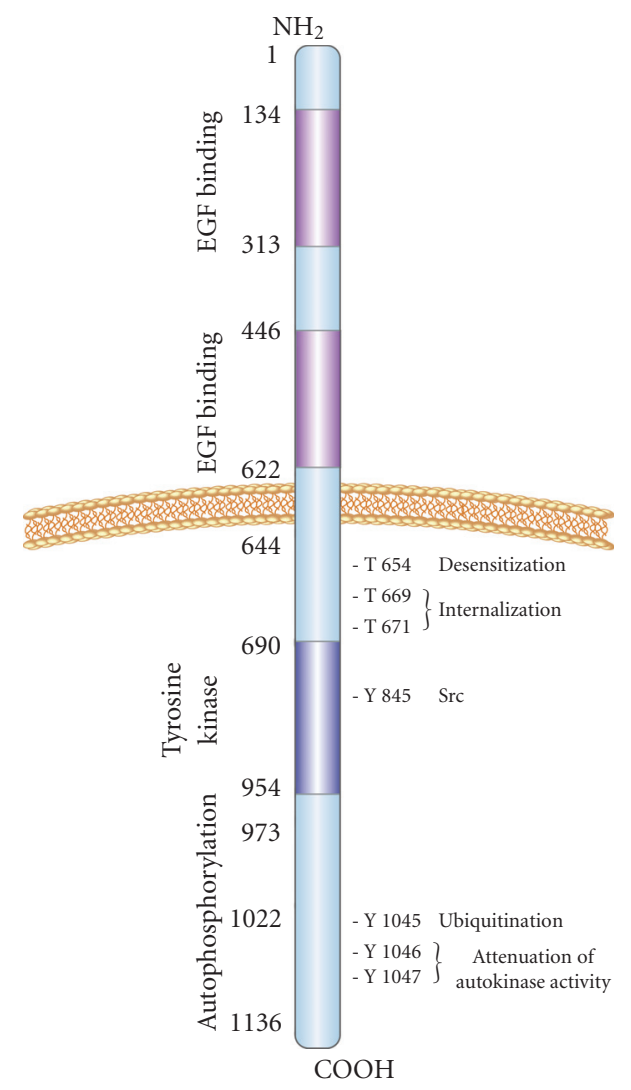

FIGURE 1: Structure of EGFR. EGFR consists of extracellular, transmembrane, and intracellular domains. The extracellular domain is the least conserved domain among the EGFR family members and consists of 4 subdomains - two ligand-binding domains and two receptor dimerization domains, which are cysteine-rich (reviewed in [12]). The transmembrane domain, which spans the cell membrane, is hydrophobic. The cytoplasmic tail of the EGFR family is highly conserved and contains the tyrosine kinase domain. Activation of EGFR family members leads to autophosphorylation of the tyrosine residues in the cytoplasmic tail. The phosphorylated tyrosine residues become docking sites for proteins with SRC homology 2 and phosphotyrosine binding domains, which transduce the signals downstream. EGFR phosphorylation at selected residues and their functional outcomes are indicted in the diagram. T: threonine; Y: tyrosine.

family members in the membrane, type and proportion of ligand (reviewed in $[10,13]$ ), and cell lineage likely reflected in the expression of additional members of the signaling complex (see below). Strikingly, HER2 is the preferred binding partner for all EGFR family members [14], while HER3 is an obligatory partner [15], being inactive on its own or as a homodimer as it lacks intrinsic kinase activity due to mutation of critical amino acids in the kinase domain $[16,17]$. This combination has lead to the suggestion by Yarden and colleagues that HER2 and HER 3 are "deaf and dumb" members of the EGFR family, functioning in normal physiology as part of signaling complexes with other EGFR family members [18].

Activation of the EGFR family members results in transduction of EGFR signals, via intracellular cascades, such as mitogen-activated protein kinases (MAPKs), and AKT (also known as protein kinase $B$ ), resulting in perturbation of multiple cellular responses including proliferation, differentiation, cell motility, and survival (reviewed in $[9,19]$ ). A summary of selected EGFR family pathways is shown in Figure 2.

The EGFR family members can also be activated by other signaling proteins independent of addition of exogenous EGFR ligands. These include other receptor tyrosine kinases (RTKs) such as insulin-like growth factor-1 receptor (IGF1R) (reviewed in $[20,21]$ ) and tyrosine kinase receptor B (TRKB, [22]) as well as other types of receptors such as G protein-coupled receptors (GPCRs) (reviewed in [23]), the leptin receptor [24], and adhesion proteins such as Ecadherin (reviewed in [25]) and integrins (reviewed in [26]). While the details of EGFR transactivation upon crosstalk are not yet fully elucidated, transactivation has been shown to occur by a variety of mechanisms. For example, there is evidence that EGFR can be transactivated by IGF-1R by direct binding [27]. Additionally, EGFR transactivation by GPCR has been shown to occur intracellularly, such as by activation of SRC upon GPCR stimulation (e.g., [28]), as well as extracellularly, such as by GPCR activation by gastrin releasing peptide [29]. This induces the formation of a GPCR complex containing SRC, Phosphatidylinositol 3'-kinase (PI3K), PDK1, and TNF- $\alpha$ converting enzyme (TACE), resulting in activation and translocation of TACE to the membrane where it releases the EGFR ligand amphiregulin, resulting in subsequent EGFR activation [29]. Lysophosphatidic acid (LPA)-GPCR-induced ectodomain shedding of pro Heparin Binding-EGF also activates EGFR [30]. LPAmediated signaling is of particular importance in ovarian cancer as abnormalities in LPA metabolism and function likely contribute to initiation and progression of ovarian cancer [31-33]. Additionally, TRKB may also play a role in ovarian cancer as its activation has been shown to enhance migration and proliferation and suppress anoikis in human ovarian cancer cells $[22,34]$.

1.2. EGFR in Ovarian Cancer. The EGFR gene, located on chromosome $7 \mathrm{p} 12$, is amplified in ovarian cancer in approximately $4 \%-22 \%$ of cases $[3,6,35,36]$, including about $13 \%$ in epithelial ovarian cancers [35]. Activating EGFR mutations, as determined by sequence analyses of potential activating mutation sites in the catalytic domain, is rare in ovarian cancer, with a frequency of $4 \%$ or less $[6,35,37]$. The constitutively active mutant EGFRvIII, while reported earlier to be detected in $73 \%(24 / 32)$ of ovarian cancers [38], was not detected in subsequent and more extensive studies examining serous [6] or various types of ovarian cancers [39]. Overexpression of the EGFR protein has been detected in $9 \%-62 \%$ of human ovarian cancers $[6,36,40,41]$; the differences in frequencies from these studies likely reflect utilization of different antibodies and cutoffs for overexpression. EGFR gene amplification or protein overexpression occurs across all epithelial ovarian cancer histotypes $[3,4]$. Increased EGFR expression has been associated with high tumor grade $[3,5,6]$, high cell proliferation index [6], aberrant P53 expression [6], and poor patient outcome $[5,6]$. 


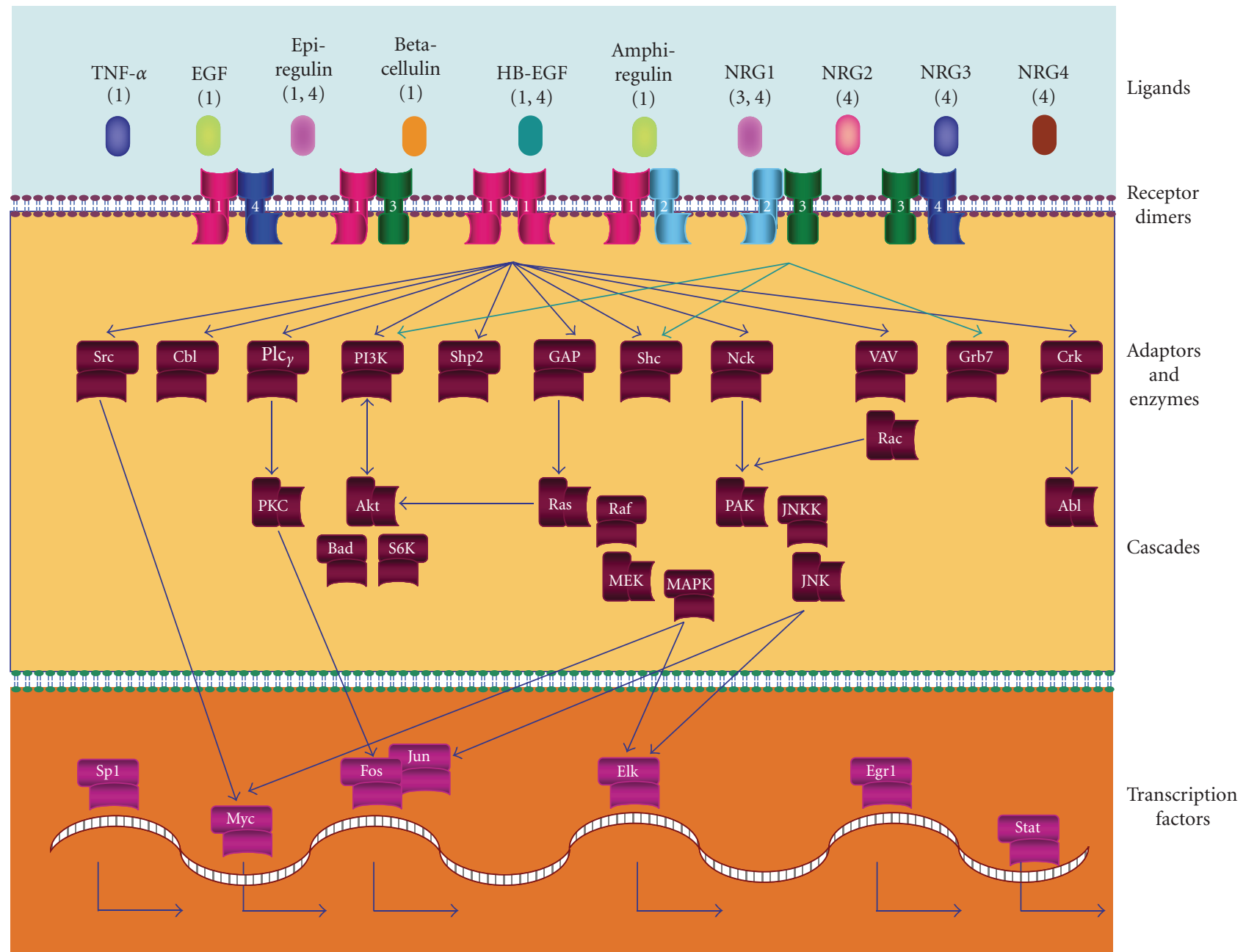

FIGURE 2: Selected representation of canonical EGFR family signaling pathways. The EGFR family consists of 4 members: EGFR, HER2, HER3, and HER4 (indicated by numbers 1-4 in the diagram). EGFR family ligands include EGF-and EGF-like ligands, transforming growth factor (TGF)- $\alpha$ and heregulins (HRGs, also known as neuregulins, NRGs). As indicated by the numbers in parentheses beneath the ligands, each ligand binds preferentially to a particular EGFR family member. HER2, while lacking any known ligand, is the preferred binding partner of for all EGFR family members. HER3 lacks intrinsic kinase activity due to mutation of critical amino acids in the kinase domain; therefore, it is inactive on its own or as a homodimer. Transduction of EGFR signals occurs through intracellular adaptor proteins, which transmit signals through cascades such as the RAS/RAF/MEK/mitogen-activated protein kinase (MAPK) and phosphatidylinositol 3'-kinase (PI3K)/AKT cascades. The downstream proteins in these signaling cascades can shuttle from the cytoplasm to the nucleus, where they signal to transcription factors and their complexes such as MYC, ELK, and FOS/JUN. Signal transduction through the EGFR family to downstream pathways and cascades controls diverse cellular responses such as proliferation, differentiation, cell motility, and survival as well as tumorigenesis. Figure adapted from [13]. Abbreviations: PLC $\gamma$ : Phospholipase C $\gamma$; SHP2: SRC homology phosphatase 2; GAP: GTPase activating protein; SHC: SRC homology 2 domain and collagen-containing protein; PKC: Protein kinase C; MEK: MAPK/ERK kinase; PAK: P21-activated kinase; JNKK: JNK kinase; JNK: JUN N-terminal kinase; EGR1: Early growth response protein 1; STAT: Signal transducer and activator of transcription.

One of the first studies implicating the EGFR pathway in ovarian cancer was the detection of TGF- $\alpha$ in human ovarian cancer effusions as determined by radioimmunoassay [42]. TGF- $\alpha$ was also shown to increase proliferation as measured by $\left[{ }^{3} \mathrm{H}\right]$ thymidine incorporation [43] as well as increase levels of the tumor markers cancer antigen-125 and tissue polypeptide antigen [44] in EGFR-positive primary human serous ovarian cancer cells. In the human ovarian adenocarcinoma cell line OMC-3, TGF- $\alpha$ induced migration and invasion as well as gelatinolytic, caseinolytic, and plasmin activity in a dose-dependent manner [45].

While initial studies suggested that EGF, due to the inability to detect transcripts in Northern blotting, might not play a significant role in ovarian cancer [43], subsequent studies indicated that exogenous EGF can also induce effects associated with transformation. Like TGF- $\alpha$, treatment of OMC-3 cells with EGF induced cell migration and invasion and degradation of extracellular matrix components [45]. 
Additionally, human ovarian cancer cell lines treated with EGF showed significant increases in expression of proteins associated with invasion (urokinase plasminogen activator and its receptor, and plasminogen activator inhibitor-1 [46]). EGF can also affect pathways associated with angiogenesis, as EGF stimulation of the human ovarian adenocarcinoma cell line OVCAR-3 leads to increased $\mathrm{H}_{2} \mathrm{O}_{2}$ levels, which in turn activates the AKT-P70S6K pathway and increases vascular endothelial growth factor transcription through hypoxiainducible factor- $1 \alpha$ expression [47].

While earlier studies focused on EGFR ligands in ovarian cancer, emerging studies examined the mechanism of EGFR activation itself. For example, Campiglio et al. detailed the activation characteristics of the EGFR family members upon addition of EGF or HRG in human ovarian cancer cell lines containing different levels of EGFR family proteins [48]. In this report, they show that the pattern of EGFR family activation in human ovarian cancer cells appears to be distinct from that of human breast cancer cell lines; while EGFR and HER2 were consistently activated upon EGF treatment, HER3 and HER4 activation depended upon the relative abundance of each receptor in ovarian cancer cells. Additionally, HER3 activation could occur independently of HER2 [48]. This complex pattern of EGFR family activation could in part explain the poor rate of response to EGFR inhibition in ovarian cancer.

Further elucidation of the effects of EGFR signaling in ovarian cancer comes from inhibition of EGFR in cultured human ovarian cancer cells. For example, treatment of the human ovarian serous epithelial cancer cell line OVCA420 with the anti-EGFR murine monoclonal antibody (mAb) C225 resulted in decreased levels of cell cycle progressionassociated proteins Cyclin-dependent kinase (CDK) 2, CDK4, and CDK6 and increased expression of the cell cycleinhibiting protein $\mathrm{P} 27^{\mathrm{Kip} 1}$, along with increased association of P27 ${ }^{\text {Kipl }}$ with the CDKs [49]. Additionally, modulation of other cell cycle proteins was observed, including decreased expression and phosphorylation of the CDK substrates $\mathrm{RB}$ and P130 and decreased protein levels of cyclin A. Modulation of these proteins upon C225 treatment was associated with an increase in the proportion of cells in the G1 phase of the cell cycle. The effects observed upon EGFR inhibition were enhanced upon combined treatment of human ovarian cancer cells with the anti-HER2 murine mAb 4D5 [49].

As transactivation pathways in various cell systems have been delineated, so have the pathways associated with EGFR family activation in ovarian cancer. For example, Vacca et al. have provided evidence that the GPCR ligand, endothelin (ET)-1, can activate EGFR in the human ovarian cancer cell line OVCA 433 [50]. ET-1 has been observed to play a role in mitogenic autocrine loops in various cultured cell types including human ovarian cancer $[51,52]$ and is proposed to contribute to tumor growth in vivo [53]. ET-1 treatment increased phosphorylation of EGFR and its downstream proteins SRC homology 2 domain and collagencontaining protein (SHC) and ERK2 as well as increased SHC-GRB2 association [50]. These effects were reversed upon pretreatment of OVCA 433 cells with the EGFR inhibitor tyrphostin AG1478 as well as the $\mathrm{ET}_{\mathrm{A}}$-specific antagonist BQ-123 [50].

More recent studies have found additional signaling molecules or pathways that contribute to EGFR-mediated malignant phenotype in human ovarian cancer cell lines, including EGFR-interleukin-6 crosstalk through Janus kinase 2/Signal transducer and activator of transcription 3 signaling to mediate epithelial-mesenchymal transition [54], coactivation of Src/EGFR and axin/glycogen synthase kinase (GSK) $-3 \beta$ pathways and induction of invasion by $\beta$-arrestin activation of the ET-A receptor [55], and Src/EGFR transactivation, cyclooxygenase- 2 expression, and cell migration upon LPA2 stimulation in CAOV-3 cells [56].

\section{Disease Models, Knockouts, and Assays for EGFR in Ovarian Cancer}

In addition to the studies alluded to above in determining the effects of molecular modulations of EGFR and its biochemical and biological effects, several other approaches for studying EGFR have been used; these are summarized in Table 1. As EGFR is an extracellular signaling protein, the assays most commonly used in examining EGFR in human ovarian cancer cell lines or tissues involve methods that directly or indirectly measure EGFR activity. Assays include methods for detecting increased levels of the EGFR gene (e.g., fluorescence in situ hybridization) or protein (e.g., immunohistochemistry, Western blotting) as well as expression of activating EGFR mutations (e.g., polymerase chain reaction + sequencing) or measurement of EGFR protein activity (e.g., Western blotting of EGFR phosphorylation sites, in vitro kinase assays).

To determine the effects of EGFR activation or inhibition in tumor formation, human ovarian tumor cells are most frequently implanted heterotopically (subcutaneously) in immunocompromised mice (Table 1). No reports of "true orthotopic" implantation such as in the ovarian bursa of mice have been found in EGFR studies in ovarian cancer, presumably due to the complex and labor-intensive nature of these procedures, while a few reports of "semiorthotopic" implantations via intraperitoneal (IP) injection were identified. While IP tumor implantation offers a model potentially more reflective of advanced ovarian cancer in the patient than subcutaneous injection [57], the difficulty in measuring tumor volume in intact mice has precluded its widespread use in anti-EGFR drug studies.

In addition to implantation of human tissues or cells via xenografts, animal models utilizing other methods of tumor formation have been used to study ovarian cancer. (For comprehensive reviews on animal tumor models, see [58-61].) Most of these animal models utilize mice, and the methods used to induce tumor formation include (1) exposure to radiation (e.g., [62]) or chemicals (carcinogens or hormones) introduced at or near the ovary (e.g., [63]), (2) syngeneic models in which spontaneously transformed murine ovarian epithelial cells are transplanted into immunocompetent mice (e.g., [64]), and (3) knockout or transgenic models in which selected genes are removed 
TABLE 1: Summary of assays used in detecting EGFR in vitro and in vivo. Aside from high-throughput methods (such as cDNA arrays, comparative genomic hybridization, and reverse phase protein arrays) and xenograft tumor assays, more broadly encompassing biological methods such as assays for invasion, migration, or gene knockouts have been excluded. cDNA: complementary DNA; PCR: polymerase chain reaction.

\begin{tabular}{|c|c|c|c|c|}
\hline EGFR assay method & Assay output & $\begin{array}{l}\text { Performed in ovarian } \\
\text { cancer? }\end{array}$ & $\begin{array}{l}\text { Platform for ovarian } \\
\text { cancer }\end{array}$ & $\begin{array}{l}\text { References for ovarian } \\
\text { cancer }\end{array}$ \\
\hline cDNA Array & $\begin{array}{l}\text { Detection of mRNA } \\
\text { levels of various genes }\end{array}$ & Yes* & $\begin{array}{l}\text { Patient tissue, Human } \\
\text { cell lines }\end{array}$ & {$[172]$} \\
\hline $\begin{array}{l}\text { Comparative Genomic } \\
\text { Hybridization }\end{array}$ & $\begin{array}{l}\text { Detection of copy } \\
\text { number changes in } \\
\text { chromosomes }\end{array}$ & Yes* & $\begin{array}{l}\text { Patient tissue, Human } \\
\text { cell lines }\end{array}$ & {$[173]$} \\
\hline $\begin{array}{l}\text { Chromatin } \\
\text { Immunoprecipitation }\end{array}$ & $\begin{array}{l}\text { Detection of stable } \\
\text { protein-DNA } \\
\text { associations }\end{array}$ & No & & \\
\hline $\begin{array}{l}\text { Coimmunoprecipitation } \\
+ \text { Western blotting }\end{array}$ & $\begin{array}{l}\text { Detection of stable } \\
\text { protein-protein } \\
\text { associations }\end{array}$ & No & & \\
\hline Crystallography & $\begin{array}{l}\text { Determination of entire } \\
\text { structure or portions of } \\
\text { molecule; interacting } \\
\text { molecules }\end{array}$ & No & & \\
\hline $\begin{array}{l}\text { Enzyme-linked } \\
\text { Immunosorbent Assay }\end{array}$ & $\begin{array}{l}\text { Determination of } \\
\text { amount of protein in } \\
\text { sample }\end{array}$ & Yes & Patient tissue & {$[174]$} \\
\hline $\begin{array}{l}\text { Fluorescence/ } \\
\text { Chromogenic in situ } \\
\text { Hybridization }\end{array}$ & $\begin{array}{l}\text { Determination of gene } \\
\text { copy number }\end{array}$ & Yes & Patient tissue & {$[3,6,35,36]$} \\
\hline $\begin{array}{l}\text { Flow Cytometry/ } \\
\text { Fluorescence-Activated } \\
\text { Cell Sorting }\end{array}$ & $\begin{array}{l}\text { Determination of } \\
\text { protein levels at cell } \\
\text { surface }\end{array}$ & Yes & $\begin{array}{l}\text { Patient tissue, Human } \\
\text { cell lines }\end{array}$ & {$[175-179]$} \\
\hline $\begin{array}{l}\text { Immuno- } \\
\text { histochemistry/ } \\
\text { Immunocyto-chemistry/ } \\
\text { Immunofluorescence } \\
\text { (includes Tissue } \\
\text { Microarrays) }\end{array}$ & $\begin{array}{l}\text { Determination of } \\
\text { presence, location, or } \\
\text { amount of protein in } \\
\text { tissue/cell }\end{array}$ & Yes & $\begin{array}{l}\text { Patient tissue, Patient } \\
\text { effusions, Human cell } \\
\text { lines }\end{array}$ & $\begin{array}{l}{[4,5,35-} \\
37,40,41,43,46,97 \\
117,123,178,180-195]\end{array}$ \\
\hline In vitro Kinase Assay & $\begin{array}{l}\text { Measurement of } \\
\text { intrinsic kinase activity }\end{array}$ & No & & \\
\hline $\begin{array}{l}\text { Mass Spectrometry after } \\
\text { Protein Enrichment } \\
\text { /Purification (e.g., } \\
\text { Immunoprecipitation, } \\
\text { Chromatographic } \\
\text { Separation, Baculovirus } \\
\text { Expression) }\end{array}$ & $\begin{array}{l}\text { Detection of protein } \\
\text { modification sites (e.g., } \\
\text { phosphorylation, } \\
\text { glycosylation); changes } \\
\text { in protein levels or } \\
\text { proteomic profiles, } \\
\text { protein-protein } \\
\text { complexes }\end{array}$ & No & & \\
\hline $\begin{array}{l}\text { Microscopic Techniques } \\
\text { (e.g., Confocal) }\end{array}$ & $\begin{array}{l}\text { Determination of } \\
\text { presence, location, or } \\
\text { amount of protein in cell }\end{array}$ & No & & \\
\hline $\begin{array}{l}\text { Mulitplex Antibody } \\
\text { Arrays (Solid Phase or } \\
\text { Bead Based) }\end{array}$ & $\begin{array}{l}\text { Detection of multiple } \\
\text { molecules (usually } \\
\text { proteins) of interest }\end{array}$ & Yes* & $\begin{array}{l}\text { Patient serum, Human } \\
\text { cell lines }\end{array}$ & {$[196,197]$} \\
\hline Northern Blotting & $\begin{array}{l}\text { Determination of } \\
\text { steady-state RNA levels }\end{array}$ & Yes & $\begin{array}{l}\text { Patient tissue, Human } \\
\text { cell lines }\end{array}$ & {$[43,186,193,198,199]$} \\
\hline $\begin{array}{l}\text { PCR + DNA analysis } \\
\text { (e.g., Sequencing, } \\
\text { Restriction Fragment } \\
\text { Length Polymorphisms, } \\
\text { Denaturing Gradient } \\
\text { Gel Electrophoresis) }\end{array}$ & $\begin{array}{l}\text { Detection of known } \\
\text { mutations/ } \\
\text { polymorphisms }\end{array}$ & Yes & $\begin{array}{l}\text { Patient tissue, Human } \\
\text { cell lines }\end{array}$ & $\begin{array}{l}{[6,35-} \\
37,117,130,187,200]\end{array}$ \\
\hline
\end{tabular}


TABle 1: Continued.

\begin{tabular}{|c|c|c|c|c|}
\hline EGFR assay method & Assay output & $\begin{array}{l}\text { Performed in ovarian } \\
\text { cancer? }\end{array}$ & $\begin{array}{l}\text { Platform for ovarian } \\
\text { cancer }\end{array}$ & $\begin{array}{l}\text { References for ovarian } \\
\text { cancer }\end{array}$ \\
\hline Quantitative PCR & $\begin{array}{l}\text { Measurement of RNA } \\
\text { levels of interest }\end{array}$ & Yes & Human cell lines & {$[39,174,201]$} \\
\hline $\begin{array}{l}\text { Radioligand Binding/ } \\
\text { Radioimmunoassay }\end{array}$ & $\begin{array}{l}\text { Estimation of number of } \\
\text { receptors; determination } \\
\text { of ligand or agonist/ } \\
\text { antagonist binding } \\
\text { kinetics }\end{array}$ & Yes & $\begin{array}{l}\text { Patient tissue, Patient } \\
\text { effusions, Human cell } \\
\text { lines }\end{array}$ & {$[42-45,199]$} \\
\hline $\begin{array}{l}\text { Reverse Phase Protein } \\
\text { Array }\end{array}$ & $\begin{array}{l}\text { Determination of levels } \\
\text { of several proteins and } \\
\text { protein modifications of } \\
\text { interest }\end{array}$ & Yes & $\begin{array}{l}\text { Patient tissue, Patient } \\
\text { effusions }\end{array}$ & {$[202,203]$} \\
\hline $\begin{array}{l}\text { Reverse } \\
\text { Transcription-PCR + } \\
\text { Southern Blotting }\end{array}$ & $\begin{array}{l}\text { Determination of } \\
\text { mRNA levels }\end{array}$ & Yes & $\begin{array}{l}\text { Human cell lines, Rat } \\
\text { cell lines }\end{array}$ & {$[198,204]$} \\
\hline Southern Blotting & $\begin{array}{l}\text { Detection of gene of } \\
\text { interest }\end{array}$ & Yes & Rat cell lines & {$[198]$} \\
\hline $\begin{array}{l}\text { Tryptic Digests + } \\
\text { Peptide Resolution (e.g., } \\
\text { Reverse Phase High } \\
\text { Performance Liquid } \\
\text { Chromatography) }\end{array}$ & $\begin{array}{l}\text { Determination of } \\
\text { phosphorylation sites of } \\
\text { protein }\end{array}$ & No & & \\
\hline Western Blotting & $\begin{array}{l}\text { Determination of } \\
\text { protein abundance, } \\
\text { protein-associated } \\
\text { modifications (e.g., } \\
\text { phosphorylation, } \\
\text { cleavage, ubiquitination) }\end{array}$ & Yes & $\begin{array}{l}\text { Patient tissue, Human } \\
\text { cell lines }\end{array}$ & $\begin{array}{l}{[38,39,46,48-} \\
50,56,147,175,177, \\
178,181,186,196,200, \\
201,204-212]\end{array}$ \\
\hline Xenograft Tumors & $\begin{array}{l}\text { Determination of effect } \\
\text { of gene/cell perturbation } \\
\text { on tumor growth }\end{array}$ & Yes & $\begin{array}{l}\text { Human and mouse cell } \\
\text { lines }\end{array}$ & $\begin{array}{l}{[47,49,147,178,213-} \\
219]\end{array}$ \\
\hline
\end{tabular}

*EGFR was detected and reported, but samples were not necessarily preselected for alteration of EGFR sequence, expression, or activity.

or activated within the mouse. While none of these methods have directly examined the role of EGFR aberrations in ovarian cancer, some of these methods have been applied to other tumor models (e.g., glioma [65], lung adenocarcinoma [66]) in which EGFR perturbations (activating mutations) have been studied, indicating that EGFR-mediated tumor development can be successfully developed in transgenic mice.

In one study where signaling proteins downstream of EGFR induced ovarian cancer, transgenic mice harboring exogenously controllable ("floxed") expression of phosphatase and tensin homolog (PTEN) and mutated K-RAS genes were induced to gain oncogenic $\mathrm{K}-\mathrm{RAS}$ and lose tumor suppressing PTEN expression in the ovaries via injection of an adenovirus-Cre recombinase vector into the infundibulum [67]. All animals developed endometrioid adenocarcinoma of the ovary and, unlike previous ovarian tumor models, were well differentiated, reflecting similar histomorphology to human epithelial ovarian cancers. Thus, this model allows for detailed study of the endometrioid subtype of epithelial ovarian cancer at various stages of tumor development and with some manipulations could be used to study the effects of EGFR aberrations in ovarian tumor development. Mouse models for other subtypes of epithelial ovarian cancers (serous, mucinous, clear cell, transitional) await further development.

\section{Targeting EGFR in Ovarian Cancer}

While several strategies have been attempted to block EGFR activity, two types of inhibitors are currently used in the clinic: (1) monoclonal antibodies (mAbs), and (2) small molecule tyrosine kinase inhibitors (see $[68,69]$ for reviews). A summary of these inhibitors and their uses in clinical trials is shown in Table 2. While the various natural functions of antibodies may contribute to their utility as anticancer agents, including their role as modulators or effectors of the immune response, molecular carriers, and pharmacologic agents that directly interfere with activation of the receptor and its downstream pathways (reviewed in [70]), the focus of this paper will be on mAbs as pharmacologic agents. As indicated above by the in vitro studies in human ovarian cancer cells, EGFR and its downstream effectors may be activated directly or indirectly by numerous other signaling molecules. Since determination of which molecules are key to EGFR signaling in ovarian cancers is 
not completely understood, the focus will be on inhibition of EGFR and its family members.

3.1. Anti-EGFR Monoclonal Antibodies. Anti-EGFR mAbs that are used in the clinic typically bind to the extracellular domain of EGFR (e.g., [71, 72]). While there are potentially many different mechanisms of inhibition, in many of the known cases, the antibodies prevent ligand binding (in the case of wild-type EGFR), promote antibody-receptor complex internalization [73-75], induce transient decrease of EGFR expression [76], inhibit EGFR heterodimerization $[72,77,78]$, and increase ubiquitin-mediated degradation [79]. The downstream effects of inhibition in EGFRdependent cancer cells include decreased TGF- $\alpha$ secretion, angiogenesis, cell migration, invasion (reviewed in [80]), and induction of apoptosis [81]. Additionally, certain engineered IgG subclass antibodies in which the $F_{c}$ region is maintained can induce antibody-dependent cell-mediated cytotoxicity or complement activation (see $[82,83]$ for comprehensive reviews). To reduce the likelihood of patient immune response against the therapeutic antibody, mouse mAbs have been humanized (reviewed in [84]); these are reflected by their antibody names. For example, humanmouse chimeric antibodies of $30 \%$ mouse composition are designated as "-ximab" (e.g., cetuximab); humanized antibodies with $10 \%$ mouse composition are given the "zumab" designation (e.g., trastuzumab, matuzumab), while fully humanized antibodies are designated as "-mumab" (e.g., panitumumab).

Cetuximab (Erbitux) was the first anti-EGFR mAb tested in the clinic. Cetuximab inhibits growth of a variety of cultured cancer cells including breast, prostate, lung, colon, kidney, head and neck (reviewed in [85]), pancreas [86], and bladder [87] and can induce regression (either alone or as a combined therapy) of a number of human tumor xenografts such as epidermoid carcinoma [88], renal cell carcinoma [89], pancreatic cancer [86, 90], non-small cell lung cancer (NSCLC) [91], thyroid carcinoma [92], and glioblastoma multiforme [93]. Cetuximab demonstrates activity in patients with colorectal, head and neck, and lung cancers $[94,95]$.

Reports for cetuximab in ovarian cancers have appeared recently (Table 2), including its use as a single agent in a phase II trial [96] and in two other phase II trials in combination with carboplatin with or without paclitaxel (Taxol) [97, 98]. In all studies, EGFR positivity was determined by immunohistochemistry (IHC) and in two cases was used among the criteria for inclusion $[96,98]$. Cetuximab therapy alone showed 4\% (1/25 patients) partial response (PR) [96], while the cetuximab + carboplatin trial showed $12 \%$ (3/26 patients) complete response (CR) and 23\% (6/26 patients) PR [97]. While no response rate was reported in the cetuximab + carboplatin + paclitaxel trial, progression-free survival (PFS) at 18 months was $39 \%$, which did not meet the authors' criteria for meaningful response [98] and did not proceed to the next phase of accrual. There was no evidence of correlation between EGFR levels and patient response in any of the reports. The implications of these and subsequent results will be discussed in the "Next frontiers" section.
Among other anti-EGFR antibodies, a single multiinstitution open-label phase II trial was reported in patients with ovarian cancer using matuzumab (EMD 72000) [99]. While screening for this phase II trial included EGFR positivity in the ovarian tumor as determined by IHC, no responses to therapy were observed. To date there are no approved anti-EGFR antibodies for ovarian cancer, and while there was one clinical trial involving panitumumab (Vectibix) in combination with AMG 706 and gemcitabine-cisplatin in patients with advanced cancers (including ovarian), this trial was terminated. Currently, there are no full reports of clinical trials for ovarian cancer with other anti-EGFR antibodies such as zalutumumab (HuMax-EGFr) and nimotuzumab $\left(\mathrm{BIOMAb}{ }^{\mathrm{EGFR}}\right)$. Among patented mAbs directed towards EGFR that are not yet in clinical use, one has been proposed for use in ovarian cancer (patent number WO2005010151); however, as it is directed against deletion mutants of EGFR (particularly EGFRvIII), its use in ovarian cancer is likely to be limited.

Due to potential EGFR transactivation by other EGFR family members, mAbs targeting other EGFR family members have also been tested or used clinically against various cancer types such as breast and urothelial malignancies (reviewed in [100]). This includes clinical trials targeting HER2 such as a phase II multi-institutional trial in ovarian cancer in which trastuzumab (Herceptin) was used as a single agent in patients determined HER2 positive by IHC [101]. An overall response rate of $7.3 \%$ (1 CR, 2 PR) was reported. However, the relatively low frequency of HER 2 amplification in unselected ovarian cancers (e.g., $10 \%-23 \%$; $[35,102])$ has precluded more extensive studies. Pertuzumab (Omnitarg), a HER2 dimerization inhibitor, was administered with gemcitabine (Gemzar) in platinum-resistant ovarian cancer patients in a phase II safety study [103]; efficacy awaits further reports.

Among antibodies targeted toward other signaling molecules known to activate EGFR are monoclonals for IGF1R, including 19D12 and EM164. These antibodies have been demonstrated to inhibit proliferation of human ovarian cancer cells [104] as well as tumor growth in mouse xenograft studies [105]. However, whether EGFR aberrations affect response to anti-IGF-1R treatment or whether inhibition can be enhanced by anti-EGFR treatment is unknown.

3.2. Small Molecule EGFR Inhibitors. Small molecule inhibitors, based on modeling by structure-based drug design [106] or by screening (e.g., erlotinib, [107]), appear to act intracellularly by competing with ATP binding in the catalytic region of the kinase domain, thereby abrogating enzymatic activity of the kinase and its subsequent downstream signaling effects (reviewed in [108]). Small molecule inhibitors directed against EGFR generally prevent homo- and heterodimerization between it and other EGFR family members; however, in some cases the inhibitor allows heterodimerization but prevents activation of these dimers [109]. While most mAbs are designed to target full length EGFR, many small molecule inhibitors can target mutant RTKs such as EGFRvIII that lack a critical extracellular regulatory region targeted by some of the antibodies. Small 
TABLE 2: Summary of clinical trials using EGFR inhibitors in ovarian cancers References are in parentheses next to the first author of the study. CT: clinical trial; IHC: immunohistochemistry; RPPA: reverse phase protein array; CR: complete response; PR: partial response; SD: stable disease; pt: patient; PFS: progression free survival; GOG: Gynecologic Oncology Group; VEGFR: vascular endothelial growth factor receptor.

(a) Monoclonal Antibodies

\begin{tabular}{|c|c|c|c|c|c|c|c|}
\hline Study and Yea & r CT no. & Phase & \# Pts & Therapy & Selection criteria & Outcome & Comments \\
\hline $\begin{array}{l}\text { Secord et al. } \\
2008 \text { [97] }\end{array}$ & $\begin{array}{l}\text { NCT } \\
00086892\end{array}$ & II & 28 & $\begin{array}{l}\text { Cetuximab + } \\
\text { Carboplatin }\end{array}$ & $\begin{array}{l}\text { Recurrent, platinum-sensitive } \\
\text { disease }\end{array}$ & $\begin{array}{l}\text { CR: } 3 \text { pts } \\
\text { PR: } 6 \text { pts } \\
\text { SD: } 8 \text { pts }\end{array}$ & $\begin{array}{l}\text { Response rate criteria not met for } \\
\text { next stage of accrual. } 26 \text { pts were } \\
\text { EGFR positive by IHC. }\end{array}$ \\
\hline
\end{tabular}

$\begin{array}{ll}\begin{array}{l}\text { Konner et al. } \\ 2008[98]\end{array} & \text { NCT } 00063401\end{array}$ II $\quad 40 \begin{aligned} & \text { Cetuximab + Grade III-IV debulked tumor, } \\ & \begin{array}{l}\text { Paclitaxel }+ \\ \text { Carboplatin }\end{array}\end{aligned}$

Schilder et al. 2009 [96]

II 25 Cetuximab

Persistent or recurrent ovarian or primary peritoneal disease, EGFR positive tumors by IHC
PR: $1 \mathrm{pt}$ SD: 9 pts

12 serologic markers examined before and during treatment. No correlation between PFS and marker changes, but high baseline of markers associated with earlier disease progression.

No objective Primary objective was

response pharmacodynamic; signal

SD:

16\%-22\% were screened for EGFR status.

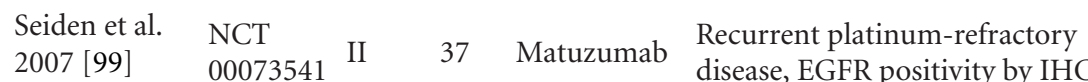

Bookman et al. GOG-160 II 41 Trastuzumab
Persistent and/or refractory disease with 2-3+ HER2 by IHC
CR: 1 pt

PR: 2 pts
Serum HER2 levels not associated with clinical outcome.

(b) Small Molecule Inhibitors

\begin{tabular}{|c|c|c|c|c|c|c|}
\hline Study and Year CT no. & Phase & \# Pts & Therapy & Selection criteria & Outcome & Comments \\
\hline $\begin{array}{ll}\text { Posadas et al. } & \text { NCT } \\
2007 \text { [203] } & 00049556\end{array}$ & II & 24 & Gefitinib & Platinum-refractory disease & $\begin{array}{l}\text { No objective } \\
\text { response } \\
\text { SD: } 37 \% \text { for } \\
>2 \text { months }\end{array}$ & $\begin{array}{l}\text { Protein correlates done with RPPA. } \\
\text { No significant correlation between } \\
\text { EGFR phosphorylation and tumor } \\
\text { response }\end{array}$ \\
\hline
\end{tabular}

Schilder et al. NCT

2005 [112] 00023699

27

Gefitinib

Persistent or recurrent disease

PR: 1 pt

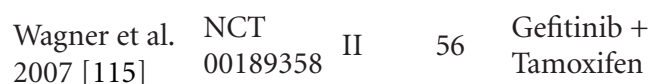

Disease refractory or resistant to platinum-taxane-based therapy

Gordon et al. 2005 [116]

II $34 \quad$ Erlotinib

Relapsed or progressive disease, EGFR positivity by IHC

PR: 2 pts SD: 15 pts

No objective response SD: 16 pts

Analyses suggest trend towards responsiveness in EGFR positive (by IHC) pts. Activating mutations documented in the PR pt.

EGFR positivity not a prerequisite; EGFR status not determined

Primary goal was to estimate the objective tumor response rate to erlotinib as a single agent.

Erlotinib +

Vasey et al. 2008 [118]
45
Docetaxel + Chemonaïve pts Carboplatin
Phase Ib dose finding study.

Addition of erlotinib to other agents did not increase response rate.
CR: 5 pts

PR: 7 pts

(23 evaluable) 
(b) Continued.

\begin{tabular}{|c|c|c|c|c|c|c|}
\hline Study and Year CT no. & Phase & \# Pts & Therapy & Selection criteria & Outcome & Comments \\
\hline $\begin{array}{ll}\text { Nimeiri et al. } & \text { NCT } \\
2008 \text { [117] } & 00126542\end{array}$ & II & 13 & $\begin{array}{l}\text { Erlotinib }+ \\
\text { Bevacizumab }\end{array}$ & $\begin{array}{l}\text { Recurrent or refractory disease, } \\
\leq 2 \text { prior cytotoxic } \\
\text { chemotherapies; no previous } \\
\text { anti-EGFR or VEGFR therapies }\end{array}$ & $\begin{array}{l}\text { CR: } 1 \mathrm{pt} \\
\text { PR: } 1 \mathrm{pt}\end{array}$ & $\begin{array}{l}\text { No indication of improvement over } \\
\text { bevacizumab treatment only. No } \\
\text { EGFR mutations detected; one } \\
\text { EGFR 2+ IHC staining detected. }\end{array}$ \\
\hline $\begin{array}{ll}\text { Kimball et al. } & \text { NCT } \\
2008[122] & 00317434\end{array}$ & I & 11 & $\begin{array}{l}\text { Lapatinib + } \\
\text { Carboplatin }\end{array}$ & $\begin{array}{l}\text { Recurrent, platinum-sensitive } \\
\text { disease }\end{array}$ & $\begin{array}{l}\text { PR: } 3 \text { pts } \\
\text { SD: } 3 \text { pts }\end{array}$ & $\begin{array}{l}\text { No screening or measurement of } \\
\text { EGFR or HER2 performed. }\end{array}$ \\
\hline $\begin{array}{l}\text { Campos et al. } \\
2005[123]\end{array}$ & II & 105 & CI-1033 & Relapsed or refractory disease & $\begin{array}{l}\text { No objective } \\
\text { response } \\
\text { SD: } 26-34 \%\end{array}$ & $\begin{array}{l}\text { Baseline HER1-2 levels determined } \\
\text { by IHC. No association between } \\
\text { HER levels and SD. }\end{array}$ \\
\hline
\end{tabular}

molecule inhibitors can bind reversibly (e.g., gefitinib or erlotinib) or irreversibly (e.g., CI-1033) to EGFR. The clinical significance of these different mechanisms of inhibition is not yet known.

Gefitinib (Iressa or ZD1839), which inhibits a variety of cancer cell lines and xenograft tumors (reviewed in [110]), including ovarian [111], was tested as a single agent in two trials $[112,113]$. In both trials, EGFR aberrations were not included as selection criteria but were assayed via IHC for EGFR protein expression [112] or via reverse phase protein array (RPPA) for total and phospho-EGFR levels [113] as well as for EGFR mutations in exons 1821 via polymerase chain reaction (PCR) amplification and nucleotide sequencing [112]. In both studies, there was no CR; $0 \%-4 \%$ had PR, and 4\%-37\% had stable disease (SD) $[112,113]$. While decreased EGFR phosphorylation and expression, as determined by RPPA, was observed in $>50 \%$ of gefitinib-treated patients, this was not associated with clinical benefit or response [113]. However, EGFR positivity via IHC was associated with longer PFS [112]. Additionally, a mutation in exon 19 was detected in the one partially responding patient [112], a location that was shown to be responsive to gefitinib treatment in NSCLC patients [114].

Gefitinib was also used in combination with tamoxifen in a phase II study in Germany involving patients refractory or resistant to platinum-taxane-based treatment but not prescreened for estrogen receptor or EGFR expression [115]. While this combination therapy was well tolerated, it was reported to be ineffective against platinum refractory/resistant ovarian cancer as there were no tumor responses.

Another small molecule inhibitor, erlotinib (Tarceva), demonstrated limited activity for ovarian cancer patients in a multicenter phase II trial, with only 2 chemorefractory patients in 34 demonstrating a partial response to treatment [116]. While EGFR expression was determined by IHC, low expression was not used as a criterion for exclusion. Erlotinib has also been tested in combination with other chemotherapeutic agents, including the antivascular endothelial growth factor (VEGF) antibody bevacizumab (Avastin) in a phase II trial [117], and docetaxel (Taxotere) with carboplatin in a phase Ib trial [118]. EGFR aberration or positivity was not an inclusion criterion in either study, and EGFR status was reported in only one study [117], which examined EGFR positivity via IHC and activating mutations in exons 19 and 21 via PCR amplification and sequencing. The objective response rates were $15 \%$ (2/13 patients) for the erlotinib + bevacizumab therapy [117] and 52\% (12/23 patients) for erlotinib + docetaxel + carboplatin [118]. No EGFR mutations were detected, and one patient demonstrated EGFR positivity, but this patient was unresponsive to erlotinib + bevacizumab therapy [117]. Due to lack of improvement over bevacizumab therapy alone and two incidents of fatal gastric perforations, the erlotinib + bevacizumab study was discontinued [117]. Whether these are due to the combinatorial effects of the drugs or due to bevacizumab alone, which has been reported to induce gastric perforation [119], remains undetermined. The response rate of the erlotinib + docetaxel + carboplatin therapy was slightly lower than that of a docetaxel + carboplatin therapy previously conducted by the same group (52\% versus $59 \%$, $[118,120])$, but due to good patient tolerance of the 3-drug combination, it was recommended for further studies, particularly as maintenance therapy.

Lapatinib (Tykerb, Tyverb), a dual EGFR-HER2 inhibitor [121], was tested in a multicenter phase I trial in combination with carboplatin in patients with platinum-sensitive recurrent ovarian cancer [122]. Patients were not prescreened or measured for EGFR in this study. Three of 11 patients $(27 \%)$ had PR, and 3 patients (27\%) had SD [122]. This treatment regimen was not recommended, as it had a low response rate and significant treatment toxicities, including grade $3-$ 4 neutropenia and grade 4 thrombocytopenia. In addition, 2 other patients had treatment delays due to development of nondose limiting grade 3 neutropenia using the initial combination therapy regimen [122].

The irreversible pan-EGFR family inhibitor CI-1033 (Canertinib) was administered in a multicenter open-label phase II trial for ovarian cancer patients who had failed prior platinum-based therapy [123]. While baseline EGFR family levels were determined via IHC from archival patient tumor specimens, it was not used as a selection criterion. 
No objective response was observed, although SD was confirmed in $26 \%-34 \%$ of the patients (depending on the dosage). There was no association between EGFR family levels by IHC and stable disease.

Due to the relatively unremarkable results of anti-EGFR small molecules in earlier clinical trials, more recent trials have focused on small molecules that bind irreversibly or have a broader target range. For instance, BIBW2992 (Tovok) binds irreversibly to EGFR and HER2 and can inhibit both wild type EGFR and activated mutants of EGFR and HER2 [124]. BIBW2992 was shown to inhibit growth of human NSCLC cells implanted in nude mice more effectively than erlotinib [124]. Several phase I and II trials are underway with BIBW2992 as a single agent or in combination with various agents such as paclitaxel, cisplatin, or temozolomide (Temodar, Temodal) in patient groups consisting of various solid tumors including glioma, NSCLC, prostate, breast, and colorectal cancer (http://www.clinicaltrials.gov/). A few trials will screen patients for EGFR or HER2 status, whether by detection of gene amplification or by activating EGFR mutations. An example of a small molecule with an even broader target range is AEE788, which inhibits EGFR, HER2, and vascular endothelial growth factor receptor (VEGFR) [125]. While the current focus of AEE788 is on glioblastoma, there is also a study that assesses the safety and clinical activity of AEE788 in various solid tumors. There is currently no complete report indicating which tumor types were included, patient response, and follow up. Other small molecule EGFR family inhibitors undergoing clinical trials against solid tumors of various types (specific types not yet reported) include HKI-272 and EKB-569.

In lung cancers, sensitivity to EGFR inhibition by small molecules such as gefitinib and erlotinib is associated with EGFR mutation [126-129]. Therefore, Lacroix et al. analyzed EGFR sequences from exons 18-24 in 18 advanced epithelial ovarian carcinoma specimens from patients that displayed objective response or disease stabilization to carboplatinpaclitaxel-gefitinib treatment, along with NSCLC [130]. While 2 of 20 NSCLC samples displayed an activating deletion in exon 19 (consistent with previous reports), no EGFR mutations were detected in the ovarian carcinomas. However, the potential role of mutations, insertions, or deletions elsewhere in EGFR or other EGFR family members was not explored.

\section{Next Frontiers in Anti-EGFR Drug Discovery}

\subsection{Improving Response to EGFR Inhibitors in Ovarian Can-} cer. As detailed by the list of clinical trials, the use of EGFR inhibitors as single agents or in early combination studies in ovarian cancer has met with limited success. The regimens have included EGFR-selective or less selective inhibitors and administration as single agents or in combination with other non-EGFR antineoplastic agents. One not yet widely explored possibility is whether using a combination of an externally targeting EGFR drug (i.e., mAb) with an internally targeting drug (i.e., small molecule kinase inhibitor) would produce better results. So far, there is one complete report of a phase I study that has determined optimal doses of combined cetuximab and gefitinib therapy in patients with advanced or metastatic NSCLC previously treated with platinum therapy [131]. These patients had no detectable EGFR amplifications or K-RAS mutations. The regimen, with the exception of the development of hypomagnesemia, was well tolerated. There was no objective response; however, 4 of 13 had SD. Based on these results, the group has recommended an optimum tolerated dose to use in a phase II trial.

While later studies selected patients based on EGFR positivity or overexpression via IHC, many of these trials still demonstrated low efficacy, suggesting that other methods of EGFR detection might be better suited for pre-drug screening. Quantitative approaches to assess protein level, RNA levels, gene amplification, and mutations might prove less subjective and more robust than IHC and could be included as one of the predictors of patient response. In lung cancer, gene copy number assessed by fluorescence in situ hybridization (FISH) has been reported to indicate sensitivity to EGFR inhibition (reviewed in [132]). Whether EGFR amplification as determined by FISH is a reliable indicator of EGFR inhibitor sensitivity for other types of cancers has not yet been conclusively assessed. Additionally, it is possible that gene increase is associated with mutational activation of EGFR, serving as a surrogate marker for mutation, and would suggest that screening by FISH might be limited to cancers in which EGFR is frequently mutated. At any rate, clinical trials in which better-defined measurements of EGFR status are taken into consideration have been emerging, such as screening of EGFR mutations in NSCLC patients prior to administration of erlotinib.

An understanding of the mechanisms leading to resistance of EGFR inhibitors could help enrich for patients likely to respond to therapy and more importantly identify rational combinatorial therapy. Resistance of tumors to anti-EGFR therapies has been discussed in a number of reviews (e.g., [133]). Furthermore, various mechanisms of chemoresistance in tumor treatment have been described (e.g., see $[134,135])$. Resistance can be apparent from the onset of treatment ("intrinsic") or develop over time ("acquired"). While resistance at the physiologic level has been attributed to mechanisms such as suboptimal immune system activity or rapid metabolism or poor absorption of the drug, resistance at the molecular level has been attributed to expression or activation of molecules or signaling pathways that can directly or indirectly override the effects of the drug (reviewed in [136]). This activation may occur via intracellular or intercellular mechanisms, and the activating intercellular source could either be another tumor cell or be the surrounding stroma (reviewed in [137]).

Anti-EGFR therapy resistance mechanisms include production of EGFR-activating ligands, receptor mutations, constitutive activation of downstream pathways, and activation of alternative signaling pathways (reviewed in $[138,139])$. Another mechanism recently suggested is increased resistance to autophagic cell death upon increased EGFR expression via stabilization of the facilitated glucose transporter sodium/glucose cotransporter 1 (SGLT1) [140]. SGLT1 can transport glucose "upstream" of a glucose 
gradient, enabling cells to accumulate higher glucose concentrations than their environment, as in the case of cancer cells, and providing more "food" for the cell [141]. Increased SGLT1 stability is dependent on EGFR expression and not its activity [140]. Thus, agents that target EGFR activity but not its expression are likely ineffective.

Another potential mechanism of EGFR inhibitor resistance is inflammation, such as by release of the inflammatory cytokine prostaglandin E2, which in lung cancer cells induced phosphorylation of MAPK, indicating a bypass of EGFR activation (reviewed in [142]). One other consideration regarding chemoresistance is the sequence or timing of multidrug administration. Proliferation of an esophageal squamous epithelial cancer cell line possessing autocrine EGFR activity was either inhibited or enhanced depending on whether a cytotoxic drug (platinum derivative or taxane) was administered before or after an EGFR inhibitor [143]. While many of these mechanisms have been studied in other cancer types, the data for ovarian cancer is currently sparse.

Experimental results have also indicated the need to better understand the interaction of EGFR with other family members, signaling events, and the tumor environment in ovarian as well as in other cancers. As noted earlier, relative differences in levels of EGFR family members induced different dimerization partners upon stimulation by a given ligand in ovarian cancer cell lines [48]. Further, there is evidence that HER3, a family member also present in ovarian cancers and associated with increased tumor aggressiveness [144] and poor prognosis [145], plays a critical role in EGFRand HER2-driven tumors (reviewed in [146]). Therefore, only targeting EGFR will likely be insufficient due to functional overlap by other EGFR family members. Also, in mouse studies using SU11925, a small molecule that targeted both EGFR and HER2, a higher concentration of SU11925 was required to inhibit HER2 phosphorylation in xenograft tumors than in cultured human or murine cells when relative HER2 levels in the cell were higher than EGFR [147]. These results point to a potential shortcoming of small molecule inhibitors in vivo.

As evident here and in numerous other reports on EGFR inhibitors in various cancer cell types, other signaling molecules affected by or effecting EGFR family members will have to be concomitantly examined in solid tumors. First, signaling of the EGFR family occurs primarily in trans with HER2 being the preferred binding partner [14]. Also, in human breast cancer cells, there is evidence that cells can escape gefitinib treatment due to increased HER3 expression induced by AKT-mediated negative feedback signaling [148]. Additionally, examining signaling proteins further downstream indicates that constitutive activation of these pathways must also be taken into consideration. For example, EGFR-overexpressing human cell lines treated with gefitinib were resistant when PTEN, the negative regulator of the PI3K/AKT pathway, was not functional $[149,150]$. In NSCLC, 0 of 8 patients with both EGFR amplification and $\mathrm{K}-R A S$ mutation responded to erlotinib treatment compared to 4 of 5 responders with EGFR amplification alone [151]. Further, tumors with RAS mutations in several cell lineages such as NSCLC, colon, and bronchioalveolar carcinoma are resistant to anti-EGFR receptor agents and may have a worsened outcome with therapy [151-153]. This is leading to widespread testing of RAS mutations in patients (such as the recent study in ovarian cancer [154]) and, indeed, is approved by the European Medicines Agency as an exclusion criterion for anti-EGFR therapy in colorectal cancer in Europe. Optimal efficacy of anti-EGFR therapy is likely to require concurrent targeting of the PI3K/AKT or RAS/MAPK pathways in patients with mutational activation of these downstream components. To this end, trials that target both EGFR and the PI3K/AKT pathway have been performed or are underway, including cancers for glial cells and head and neck. While new agents that target the PI3K/AKT pathway, including XL765 or XL147, are being tested against various solid tumors in combination with erlotinib, no known combination trials exist in ovarian cancer. Also, while trials utilizing the farnesyl transferase inhibitor lonafarnib (Sarasar), which targets RAS [155], are underway, none are currently examining the combination of EGFR and RAS inhibition in any tumor type.

In addition to signaling across EGFR family members and proteins downstream, consideration of other transmembrane signaling molecules must be taken into account. Considerable data in various cell types including hepatoma [156], prostate [21], and breast [157] has shown that EGFR inhibition can be overridden by IGFR stimulation. Moreover, there is in vitro evidence in human NSCLC and head and neck squamous cell cancer cells to support therapies combining EGFR and GPCR inhibitors, such as antagonists for bradykinin (CU201) or gastrin (PD176252) (e.g., $[158,159])$. Recently, amplification of the RTK gene MET has been shown to bypass EGFR receptor inhibition in human lung cancer cells and was present in 4 of 18 lung cancer specimens that developed resistance to gefitinib or erlotinib, supporting the idea that MET should also be targeted in EGFR-dependent cancers [160]. On the other hand, treatment of solid tumors with the dual EGFRVEGFR inhibitor vandatanib (ZD6474 or Zactima) was ineffective [161]. Based on these reports and the emergence of numerous potential EGFR-mediated signaling proteins of interest in ovarian cancers, determination of which proteins play crucial roles in ovarian tumors might prove to be a challenging process. High-throughput methods such as gene expression arrays and RPPA should help in determining which genes and proteins are modulated upon single and combination treatment of ovarian cancer cell lines and tissues. For example, Skvortsov et al. have used 2-dimensional gel electrophoresis and mass spectrometry to identify proteins associated with sensitivity or resistance to C225 in two colon cancer cell lines [162]. Additionally, development of robust algorithms to predict effective drug combinations (e.g., [163]) should aid in streamlining highthroughput studies and increase the likelihood of finding successful combinations.

Despite these challenges, reports utilizing adherent human epithelial cancer cell lines and tumor types suggest that mechanisms of resistance and methods to overcome resistance could be determined and incorporated into 
ovarian cancer therapies. For instance, MAPK phosphorylation was not inhibited in an EGFR-positive, gefitinibresistant human bladder cancer cell line upon gefitinib treatment, while MAPK phosphorylation decreased in an EGFR-positive, gefitinib-sensitive cell line [164]. Moreover, in the gefitinib-sensitive cell line, increased GSK-3 $\beta$ activity and decreased cyclin D1 levels were observed upon gefitinib treatment and correlated with responsiveness. Additionally, platelet-derived growth factor receptor- $\beta$ (PDGFR- $\beta$ ) was observed to short circuit the EGFR/MAPK pathway in the gefitinib-resistant cells [164]. These results suggest that, in bladder cancer, MAPK kinase phosphorylation could be a marker for resistance while GSK-3 $\beta$ activation or cyclin D1 levels could be a marker for sensitivity of EGFR drug treatment, and that inhibition of both EGFR and PDGFR$\beta$ would be more effective in treatment of EGFR-positive bladder cancers than EGFR alone.

\subsection{Improving Understanding of EGFR Processes in Ovarian} Cancer. With the emergence of high-throughput technologies and their accompanying development and refinement of data analyses, reports contributing to further understanding of ovarian cancers have emerged. Among the first reports utilizing gene arrays was that of Wang et al., who identified genetic differences between human ovarian tumor specimens (comprising 5 different histopathologic types) and normal ovarian tissue [165]. Later studies expanded the number and refined the analyses of histopathologic types of samples (serous papillary, clear cell, endometrioid, undifferentiated, and adenocarcinomas) included in the analyses (e.g., [166]), as well as compared drug (primarily platinum) sensitive and resistant samples [167]. While the number of samples analyzed in depth is increasing, this number is still relatively small; whether the profile of EGFR-positive ovarian cancers is different from that of other prominent molecular markers is unknown. Moreover, the most comprehensive profiles characterized thus far have focused on gene alterations, via comparative genomic hybridization or gene microarrays (reviewed in [168, 169]), which provide an incomplete profile of ovarian cancer cells, particularly in the case of protein signaling-dependent alterations such as EGFR activation. Thus, more information derived from proteomic studies is needed.

Based on the current outcomes of EGFR targeted therapy in ovarian cancers, it is evident that patients should be screened for EGFR status including amplification and mutation; additionally, screening for other EGFR family members and key downstream effector proteins such as RAS and PTEN would be preferable. Also, while EGFR in ovarian cancers has been screened for potential activating events via presence of EGFR $I I I[38,39]$ or activating mutations in the kinase domain $[6,35-37]$, it is possible that ovarian cancers might have a yet unidentified EGFR activating "hot spot." Screening and analysis of full-length EGFR will be required to determine if this is the case.

Determination of other molecular markers for likely responders or nonresponders toward anti-EGFR therapies should also be performed; identification of such markers could be facilitated by high-throughput methods that can be correlated with patient response. High-throughput methods could also be used to aid in developing predictive models of drug combination in patients, such as by testing welldefined chemotherapeutic drugs in a large number of cancer cell lines and performing cell "population studies," to better correlate drug response with precisely defined oncogene status (e.g., specific mutations, gene amplification), such as with EGFR [170]. Further studies of other proteins affecting or affected by EGFR activity, some of which have been discussed above, should also be performed to clarify their roles in ovarian cancer, both independently and in context with EGFR activation. Further, the role of EGFR in different ovarian cancer histotypes should be examined. Additionally, preclinical combination therapy reports such as by Morelli et al. [143] suggest that more studies should be performed on determining proper scheduling of multiple therapies as well as examination of previously untested drug combinations. Also of great benefit is designing more streamlined and rational methods for performing drug combination studies, such as by development of search algorithms to determine optimal doses of combined drugs [171].

\section{Conclusion}

EGFR and its family members play a variety of roles in oncogenesis and tumor progression in different cancer and cell types. To date, clinical studies using EGFR antagonists in ovarian cancer have shown limited efficacy. As we learn more about the complexities of specific signaling changes associated with EGFR mutation and overexpression, future studies using EGFR antagonists in ovarian cancer should focus on determining reliable predictors for patient responsiveness to anti-EGFR therapy such as by obtaining good biomarker profiles and utilizing assays most appropriate to determine EGFR status as well as developing rational combination therapies with EGFR inhibitors. These determinations should be facilitated by the use of high-throughput methods, as well as development of robust algorithms to help design experiments and analyze results. Continuing these studies in ovarian and other types of cancers will increase our likelihood of achieving success in targeting EGFR-dependent tumors.

\section{References}

[1] M. H. Roh, D. Kindelberger, and C. P. Crum, "Serous tubal intraepithelial carcinoma and the dominant ovarian mass: clues to serous tumor origin?" American Journal of Surgical Pathology, vol. 33, no. 3, pp. 376-383, 2009.

[2] K. M. Feeley and M. Wells, "Precursor lesions of ovarian epithelial malignancy," Histopathology, vol. 38, no. 2, pp. 8795, 2001.

[3] I. Dimova, B. Zaharieva, S. Raitcheva, R. Dimitrov, N. Doganov, and D. Toncheva, "Tissue microarray analysis of EGFR and erbB2 copy number changes in ovarian tumors," International Journal of Gynecological Cancer, vol. 16, no. 1, pp. 145-151, 2006.

[4] C.-K. Lin, T.-K. Chao, C.-P. Yu, M.-H. Yu, and J.-S. Jin, “The expression of six biomarkers in the four most common ovarian cancers: correlation with clinicopathological parameters," APMIS, vol. 117, no. 3, pp. 162-175, 2009. 
[5] H. Brustmann, "Epidermal growth factor receptor expression in serous ovarian carcinoma: an immunohistochemical study with galectin-3 and cyclin D1 and outcome," International Journal of Gynecological Pathology, vol. 27, no. 3, pp. 380-389, 2008.

[6] H. Lassus, H. Sihto, A. Leminen, et al., "Gene amplification, mutation, and protein expression of EGFR and mutations of ERBB2 in serous ovarian carcinoma," Journal of Molecular Medicine, vol. 84, no. 8, pp. 671-681, 2006.

[7] N. J. Maihle, A. T. Baron, B. A. Barrette, et al., "EGF/ErbB receptor family in ovarian cancer," Cancer Treatment and Research, vol. 107, pp. 247-258, 2002.

[8] Y. Yarden and A. Ullrich, "Growth factor receptor tyrosine kinases," Annual Review of Biochemistry, vol. 57, pp. 443-478, 1988.

[9] J. Boonstra, P. Rijken, B. Humbel, F. Cremers, A. Verkleij, and P. Van Bergen en Henegouwen, "The epidermal growth factor," Cell Biology International, vol. 19, no. 5, pp. 413-430, 1995.

[10] N. Prenzel, O. M. Fischer, S. Streit, S. Hart, and A. Ullrich, "The epidermal growth factor receptor family as a central element for cellular signal transduction and diversification," Endocrine-Related Cancer, vol. 8, no. 1, pp. 11-31, 2001.

[11] Y. Yarden, "The EGFR family and its ligands in human cancer: signalling mechanisms and therapeutic opportunities," European Journal of Cancer, vol. 37, supplement 4, pp. S3-S8, 2001.

[12] J. M. Lafky, J. A. Wilken, A. T. Baron, and N. J. Maihle, "Clinical implications of the ErbB/epidermal growth factor (EGF) receptor family and its ligands in ovarian cancer," Biochimica et Biophysica Acta, vol. 1785, no. 2, pp. 232-265, 2008.

[13] A. Zaczek, B. Brandt, and K. P. Bielawski, "The diverse signaling network of EGFR, HER2, HER3 and HER4 tyrosine kinase receptors and the consequences for therapeutic approaches," Histology and Histopathology, vol. 20, no. 3, pp. 1005-1015, 2005.

[14] E. Tzahar, H. Waterman, X. Chen, et al., "A hierarchical network of interreceptor interactions determines signal transduction by Neu differentiation factor/neuregulin and epidermal growth factor," Molecular \& Cellular Biology, vol. 16, no. 10, pp. 5276-5287, 1996.

[15] P. M. Guy, J. V. Platko, L. C. Cantley, R. A. Cerione, and K. L. Carraway III, "Insect cell-expressed p180(erbB3) possesses an impaired tyrosine kinase activity," Proceedings of the National Academy of Sciences of the United States of America, vol. 91, no. 17, pp. 8132-8136, 1994.

[16] G. D. Plowman, G. S. Whitney, M. G. Neubauer, et al., "Molecular cloning and expression of an additional epidermal growth factor receptor-related gene," Proceedings of the National Academy of Sciences of the United States of America, vol. 87, no. 13, pp. 4905-4909, 1990.

[17] S. L. Sierke, K. Cheng, H.-H. Kim, and J. G. Koland, "Biochemical characterization of the protein tyrosine kinase homology domain of the ErbB3 (HER3) receptor protein," Biochemical Journal, vol. 322, no. 3, pp. 757-763, 1997.

[18] A. Citri, K. B. Skaria, and Y. Yarden, "The deaf and the dumb: the biology of ErbB-2 and ErbB-3," Experimental Cell Research, vol. 284, no. 1, pp. 54-65, 2003.

[19] S. Morandell, T. Stasyk, S. Skvortsov, S. Ascher, and L. A. Huber, "Quantitative proteomics and phosphoproteomics reveal novel insights into complexity and dynamics of the EGFR signaling network," Proteomics, vol. 8, no. 21, pp. 4383-4401, 2008.
[20] T. E. Adams, N. M. McKern, and C. W. Ward, "Signalling by the type 1 insulin-like growth factor receptor: interplay with the epidermal growth factor receptor," Growth Factors, vol. 22, no. 2, pp. 89-95, 2004.

[21] H. E. Jones, J. M. W. Gee, I. R. Hutcheson, J. M. Knowlden, D. Barrow, and R. I. Nicholson, "Growth factor receptor interplay and resistance in cancer," Endocrine-Related Cancer, vol. 13, supplement 1, pp. S45-S51, 2006.

[22] L. Qiu, C. Zhou, Y. Sun, et al., "Crosstalk between EGFR and $\operatorname{TrkB}$ enhances ovarian cancer cell migration and proliferation," International Journal of Oncology, vol. 29, no. 4, pp. 1003-1011, 2006.

[23] A. Gschwind, E. Zwick, N. Prenzel, M. Leserer, and A. Ullrich, "Cell communication networks: epidermal growth factor receptor transactivation as the paradigm for interreceptor signal transmission," Oncogene, vol. 20, no. 13, pp. 1594$1600,2001$.

[24] D. Shida, J. Kitayama, K. Mori, T. Watanabe, and H. Nagawa, "Transactivation of epidermal growth factor receptor is involved in leptin-induced activation of Janus-activated kinase 2 and extracellular signal-regulated kinase $1 / 2$ in human gastric cancer cells," Cancer Research, vol. 65, no. 20, pp. 9159-9163, 2005.

[25] C. D. Andl and A. K. Rustgi, "No one-way street: crosstalk between E-cadherin and receptor tyrosine kinase (RTK) signaling: a mechanism to regulate RTK activity," Cancer Biology and Therapy, vol. 4, no. 1, pp. 28-31, 2005.

[26] S. Cabodi, L. Moro, E. Bergatto, et al., "Integrin regulation of epidermal growth factor (EGF) receptor and of EGFdependent responses," Biochemical Society Transactions, vol. 32, no. 3, pp. 438-442, 2004.

[27] J. Riedemann, M. Takiguchi, M. Sohail, and V. M. Macaulay, "The EGF receptor interacts with the type 1 IGF receptor and regulates its stability," Biochemical and Biophysical Research Communications, vol. 355, no. 3, pp. 707-714, 2007.

[28] E.-M. Hur, Y.-S. Park, B. D. Lee, et al., "Sensitization of epidermal growth factor-induced signaling by bradykinin is mediated by c-Src: implications for a role of lipid microdomains," The Journal of Biological Chemistry, vol. 279, no. 7, pp. 5852-5860, 2004.

[29] Q. Zhang, S. M. Thomas, V. W. Y. Lui, et al., "Phosphorylation of TNF- $\alpha$ converting enzyme by gastrin-releasing peptide induces amphiregulin release and EGF receptor activation," Proceedings of the National Academy of Sciences of the United States of America, vol. 103, no. 18, pp. 6901-6906, 2006.

[30] S. Miyamoto, H. Yagi, F. Yotsumoto, T. Kawarabayashi, and E. Mekada, "Heparin-binding epidermal growth factorlike growth factor as a novel targeting molecule for cancer therapy," Cancer Science, vol. 97, no. 5, pp. 341-347, 2006.

[31] S. Yu, M. M. Murph, Y. Lu, et al., "Lysophosphatidic acid receptors determine tumorigenicity and aggressiveness of ovarian cancer cells," Journal of the National Cancer Institute, vol. 100, no. 22, pp. 1630-1642, 2008.

[32] G. B. Mills and W. H. Moolenaar, "The emerging role of lysophosphatidic acid in cancer," Nature Reviews Cancer, vol. 3, no. 8, pp. 582-591, 2003.

[33] X. Fang, M. Schummer, M. Mao, et al., "Lysophosphatidic acid is a bioactive mediator in ovarian cancer," Biochimica et Biophysica Acta, vol. 1582, no. 1-3, pp. 257-264, 2002.

[34] X. Yu, L. Liu, B. Cai, Y. He, and X. Wan, "Suppression of anoikis by the neurotrophic receptor TrkB in human ovarian cancer," Cancer Science, vol. 29, no. 3, pp. 543-552, 2008. 
[35] J. Vermeij, E. Teugels, C. Bourgain, et al., "Genomic activation of the EGFR and HER2-neu genes in a significant proportion of invasive epithelial ovarian cancers," $B M C$ Cancer, vol. 8, article 3, 2008.

[36] S. Stadlmann, U. Gueth, U. Reiser, et al., "Epithelial growth factor receptor status in primary and recurrent ovarian cancer," Modern Pathology, vol. 19, no. 4, pp. 607-610, 2006.

[37] R. J. Schilder, M. W. Sill, X. Chen, et al., "Phase II study of gefitinib in patients with relapsed or persistent ovarian or primary peritoneal carcinoma and evaluation of epidermal growth factor receptor mutations and immunohistochemical expression: a Gynecologic Oncology Group Study," Clinical Cancer Research, vol. 11, no. 15, pp. 5539-5548, 2005.

[38] D. K. Moscatello, M. Holgado-Madruga, A. K. Godwin, et al., "Frequent expression of a mutant epidermal growth factor receptor in multiple human tumors," Cancer Research, vol. 55, no. 23, pp. 5536-5539, 1995.

[39] K. D. Steffensen, M. Waldstrøm, D. Olsen, et al., "Mutant epidermal growth factor receptor in benign, borderline, and malignant ovarian tumors," Clinical Cancer Research, vol. 14, no. 11, pp. 3278-3282, 2008.

[40] C.-H. Lee, D. G. Huntsman, M. C. U. Cheang, et al., "Assessment of Her-1, Her-2, and Her-3 expression and Her-2 amplification in advanced stage ovarian carcinoma," International Journal of Gynecological Pathology, vol. 24, no. 2, pp. 147-152, 2005.

[41] J. S. Nielsen, E. Jakobsen, B. Hølund, K. Bertelsen, and A. Jakobsen, "Prognostic significance of p53, Her-2, and EGFR overexpression in borderline and epithelial ovarian cancer," International Journal of Gynecological Cancer, vol. 14, no. 6, pp. 1086-1096, 2004.

[42] A.-R. Hanauske, C. L. Arteaga, G. M. Clark, et al., "Determination of transforming growth factor activity in effusions from cancer patients," Cancer, vol. 61, no. 9, pp. 1832-1837, 1988.

[43] K. Morishige, H. Kurachi, K. Amemiya, et al., "Evidence for the involvement of transforming growth factor $\alpha$ and epidermal growth factor receptor autocrine growth mechanism in primary human ovarian cancers in vitro," Cancer Research, vol. 51, no. 19, pp. 5322-5328, 1991.

[44] H. Kurachi, H. Adachi, K.-I. Morishige, et al., “Transforming growth factor- $\alpha$ promotes tumor markers secretion from human ovarian cancers in vitro," Cancer, vol. 78, no. 5, pp. 1049-1054, 1996.

[45] M. Ueda, H. Fujii, K. Yoshizawa, et al., "Effects of sex steroids and growth factors on invasive activity and $5^{\prime}$-deoxy-5fluorouridine sensitivity in ovarian adenocarcinoma OMC-3 cells," Japanese Journal of Cancer Research, vol. 89, no. 12, pp. 1334-1342, 1998.

[46] E. Henic, M. Sixt, S. Hansson, G. Høyer-Hansen, and B. Casslén, "EGF-stimulated migration in ovarian cancer cells is associated with decreased internalization, increased surface expression, and increased shedding of the urokinase plasminogen activator receptor," Gynecologic Oncology, vol. 101, no. 1, pp. 28-39, 2006.

[47] L.-Z. Liu, X.-W. Hu, C. Xia, et al., "Reactive oxygen species regulate epidermal growth factor-induced vascular endothelial growth factor and hypoxia-inducible factor- $1 \alpha$ expression through activation of AKT and P70S6K1 in human ovarian cancer cells," Free Radical Biology and Medicine, vol. 41, no. 10, pp. 1521-1533, 2006.
[48] M. Campiglio, S. Ali, P. G. Knyazev, and A. Ullrich, "Characteristics of EGFR family-mediated HRG signals in human ovarian cancer," Journal of Cellular Biochemistry, vol. 73, no. 4, pp. 522-532, 1999.

[49] D. Ye, J. Mendelsohn, and Z. Fan, "Augmentation of a humanized anti-HER2 mAb 4D5 induced growth inhibition by a human-mouse chimeric anti-EGF receptor mAb C225," Oncogene, vol. 18, no. 3, pp. 731-738, 1999.

[50] F. Vacca, A. Bagnato, K. J. Cart, and R. Tecce, “Transactivation of the epidermal growth factor receptor in endothelin-1induced mitogenic signaling in human ovarian carcinoma cells," Cancer Research, vol. 60, no. 18, pp. 5310-5317, 2000.

[51] A. Bagnato, R. Tecce, C. Moretti, V. Di Castro, D. Spergel, and K. J. Catt, "Autocrine actions of endothelin-1 as a growth factor in human ovarian carcinoma cells," Clinical Cancer Research, vol. 1, no. 9, pp. 1059-1066, 1995.

[52] S. Moraitis, S. P. Langdon, and W. R. Miller, "Endothelin expression and responsiveness in human ovarian carcinoma cell lines," European Journal of Cancer Part A, vol. 33, no. 4, pp. 661-668, 1997.

[53] M. Shichiri, Y. Hirata, T. Nakajima, et al., "Endothelin-1 is an autocrine/paracrine growth factor for human cancer cell lines," The Journal of Clinical Investigation, vol. 87, no. 5, pp. 1867-1871, 1991.

[54] M. Colomiere, A. C. Ward, C. Riley, et al., "Cross talk of signals between EGFR and IL-6R through JAK2/STAT3 mediate epithelial-mesenchymal transition in ovarian carcinomas," British Journal of Cancer, vol. 100, no. 1, pp. 134-144, 2009.

[55] L. Rosanò, R. Cianfrocca, S. Masi, et al., " $\beta$-arrestin links endothelin A receptor to $\beta$-catenin signaling to induce ovarian cancer cell invasion and metastasis," Proceedings of the National Academy of Sciences of the United States of America, vol. 106, no. 8, pp. 2806-2811, 2009.

[56] J. J. Kang, Y. P. Soon, H. S. Ji, et al., "Lysophosphatidic acid receptor 2 and $\mathrm{Gi} / \mathrm{Src}$ pathway mediate cell motility through cyclooxygenase 2 expression in CAOV-3 ovarian cancer cells," Experimental and Molecular Medicine, vol. 40, no. 6, pp. 607616, 2008.

[57] T. C. Hamilton, R. C. Young, and K. G. Louie, "Characterization of a xenograft model of human ovarian carcinoma which produces ascites and intraabdominal carcinomatosis in mice," Cancer Research, vol. 44, no. 11, pp. 5286-5290, 1984.

[58] K. Garson, T. J. Shaw, K. V. Clark, D.-S. Yao, and B. C. Vanderhyden, "Models of ovarian cancer-are we there yet?" Molecular and Cellular Endocrinology, vol. 239, no. 1-2, pp. 15-26, 2005.

[59] W. Shan and J. Liu, "Epithelial ovarian cancer: focus on genetics and animal models," Cell Cycle, vol. 8, no. 5, pp. 731735, 2009.

[60] K. D. S. Stakleff and V. E. Von Gruenigen, "Rodent models for ovarian cancer research," International Journal of Gynecological Cancer, vol. 13, no. 4, pp. 405-412, 2003.

[61] B. C. Vanderhyden, T. J. Shaw, and J.-F. Ethier, "Animal models of ovarian cancer," Reproductive Biology and Endocrinology, vol. 1, article 67, 2003.

[62] W. U. Gardner, "Tumorigenesis in transplanted irradiated and nonirradiated ovaries," Journal of the National Cancer Institute, vol. 26, pp. 829-853, 1961.

[63] T. Krarup, "Oocyte destruction and ovarian tumorigenesis after direct application of a chemical carcinogen (9:0dimethyl-1:2-benzanthrene) to the mouse ovary," International Journal of Cancer, vol. 4, no. 1, pp. 61-75, 1969. 
[64] K. F. Roby, C. C. Taylor, J. P. Sweetwood, et al., "Development of a syngeneic mouse model for events related to ovarian cancer," Carcinogenesis, vol. 21, no. 4, pp. 585-591, 2000.

[65] E. C. Holland, W. P. Hively, R. A. DePinho, and H. E. Varmus, "A constitutively active epidermal growth factor receptor cooperates with disruption of G1 cell-cycle arrest pathways to induce glioma-like lesions in mice," Genes \& Development, vol. 12, no. 23, pp. 3675-3685, 1998.

[66] K. Politi, M. F. Zakowski, P.-D. Fan, E. A. Schonfeld, W. Pao, and H. E. Varmus, "Lung adenocarcinomas induced in mice by mutant EGF receptors found in human lung cancers respond to a tyrosine kinase inhibitor or to down-regulation of the receptors," Genes \& Development, vol. 20, no. 11, pp. 1496-1510, 2006.

[67] D. M. Dinulescu, T. A. Ince, B. J. Quade, S. A. Shafer, D. Crowley, and T. Jacks, "Role of K-ras and Pten in the development of mouse models of endometriosis and endometrioid ovarian cancer," Nature Medicine, vol. 11, no. 1, pp. 63-70, 2005.

[68] M. J. Palayekar and T. J. Herzog, "The emerging role of epidermal growth factor receptor inhibitors in ovarian cancer," International Journal of Gynecological Cancer, vol. 18, no. 5, pp. 879-890, 2008.

[69] C. L. Arteaga, "Overview of epidermal growth factor receptor biology and its role as a therapeutic target in human neoplasia," Seminars in Oncology, vol. 29, no. 5, supplement 14, pp. 3-9, 2002.

[70] C. F. Nicodemus and J. S. Berek, "Monoclonal antibody therapy of ovarian cancer," Expert Review of Anticancer Therapy, vol. 5, no. 1, pp. 87-96, 2005.

[71] T. G. Johns, T. E. Adams, J. R. Cochran, et al., "Identification of the epitope for the epidermal growth factor receptorspecific monoclonal antibody 806 reveals that it preferentially recognizes an untethered form of the receptor," The Journal of Biological Chemistry, vol. 279, no. 29, pp. 30375-30384, 2004.

[72] S. Li, K. R. Schmitz, P. D. Jeffrey, J. J. W. Wiltzius, P. Kussie, and K. M. Ferguson, "Structural basis for inhibition of the epidermal growth factor receptor by cetuximab," Cancer Cell, vol. 7, no. 4, pp. 301-311, 2005.

[73] U. Murthy, A. Basu, U. Rodeck, M. Herlyn, A. H. Ross, and M. Das, "Binding of an antagonistic monoclonal antibody to an intact and fragmented EGF-receptor polypeptide," Archives of Biochemistry and Biophysics, vol. 252, no. 2, pp. 549-560, 1987.

[74] Z. Fan, Y. Lu, X. Wu, and J. Mendelsohn, “Antibody-induced epidermal growth factor receptor dimerization mediates inhibition of autocrine proliferation of A431 squamous carcinoma cells," The Journal of Biological Chemistry, vol. 269, no. 44, pp. 27595-27602, 1994.

[75] X.-D. Yang, X.-C. Jia, J. R. F. Corvalan, P. Wang, and C. G. Davis, "Development of ABX-EGF, a fully human anti-EGF receptor monoclonal antibody, for cancer therapy," Critical Reviews in Oncology/Hematology, vol. 38, no. 1, pp. 17-23, 2001.

[76] H. Sunada, B. E. Magun, J. Mendelsohn, and C. L. MacLeod, "Monoclonal antibody against epidermal growth factor receptor is internalized without stimulating receptor phosphorylation," Proceedings of the National Academy of Sciences of the United States of America, vol. 83, no. 11, pp. 3825-3829, 1986.

[77] V. Grünwald and M. Hidalgo, "Developing inhibitors of the epidermal growth factor receptor for cancer treatment," Journal of the National Cancer Institute, vol. 95, no. 12, pp. 851-867, 2003.
[78] R. Mandic, C. J. Rodgarkia-Dara, L. Zhu, et al., "Treatment of HNSCC cell lines with the EGFR-specific inhibitor cetuximab (Erbitux ${ }^{\circledR}$ ) results in paradox phosphorylation of tyrosine 1173 in the receptor," FEBS Letters, vol. 580, no. 20, pp. 4793-4800, 2006.

[79] Y. Lu, X. Li, K. Liang, et al., "Epidermal growth factor receptor (EGFR) ubiquitination as a mechanism of acquired resistance escaping treatment by the anti-EGFR monoclonal antibody cetuximab," Cancer Research, vol. 67, no. 17, pp. 8240-8247, 2007.

[80] M. V. Karamouzis, J. R. Grandis, and A. Argiris, "Therapies directed against epidermal growth factor receptor in aerodigestive carcinomas," Journal of the American Medical Association, vol. 298, no. 1, pp. 70-82, 2007.

[81] S.-M. Huang, J. M. Bock, and P. M. Harari, "Epidermal growth factor receptor blockade with C225 modulates proliferation, apoptosis, and radiosensitivity in squamous cell carcinomas of the head and neck," Cancer Research, vol. 59, no. 8, pp. 1935-1940, 1999.

[82] Y. Kawaguchi, K. Kono, K. Mimura, H. Sugai, H. Akaike, and H. Fujii, "Cetuximab induce antibody-dependent cellular cytotoxicity against EGFR-expressing esophageal squamous cell carcinoma," International Journal of Cancer, vol. 120, no. 4, pp. 781-787, 2007.

[83] E. Friedländera, M. Barok, J. Szöllősia, and G. Vereb, “ErbBdirected immunotherapy: antibodies in current practice and promising new agents," Immunology Letters, vol. 116, no. 2, pp. 126-140, 2008.

[84] F. Rivera, M. E. Vega-Villegas, M. F. Lopez-Brea, and R. Marquez, "Current situation of panitumumab, matuzumab, nimotuzumab and zalutumumab," Acta Oncologica, vol. 47, no. 1, pp. 9-19, 2008.

[85] J. Mendelsohn, "Epidermal growth factor receptor inhibition by a monoclonal antibody as anticancer therapy," Clinical Cancer Research, vol. 3, no. 12, pp. 2703-2707, 1997.

[86] C. J. Bruns, M. T. Harbison, D. W. Davis, et al., "Epidermal growth factor receptor blockade with C225 plus gemcitabine results in regression of human pancreatic carcinoma growing orthotopically in nude mice by antiangiogenic mechanisms," Clinical Cancer Research, vol. 6, no. 5, pp. 1936-1948, 2000.

[87] P. Perrotte, T. Matsumoto, K. Inoue, et al., "Anti-epidermal growth factor receptor antibody C225 inhibits angiogenesis in human transitional cell carcinoma growing orthotopically in nude mice," Clinical Cancer Research, vol. 5, no. 2, pp. 257265, 1999.

[88] N. I. Goldstein, M. Prewett, K. Zuklys, P. Rockwell, and J. Mendelsohn, "Biological efficacy of a chimeric antibody to the epidermal growth factor receptor in a human tumor xenograft model," Clinical Cancer Research, vol. 1, no. 11, pp. 1311-1318, 1995.

[89] M. Prewett, M. Rothman, H. Waksal, M. Feldman, N. H. Bander, and D. J. Hicklin, "Mouse-human chimeric antiepidermal growth factor receptor antibody C225 inhibits the growth of human renal cell carcinoma xenografts in nude mice," Clinical Cancer Research, vol. 4, no. 12, pp. 2957-2966, 1998.

[90] J. P. Overholser, M. C. Prewett, A. T. Hooper, H. W. Waksal, and D. J. Hicklin, "Epidermal growth factor receptor blockade by antibody IMC-C225 inhibits growth of a human pancreatic carcinoma xenograft in nude mice," Cancer, vol. 89, no. 1, pp. 74-82, 2000.

[91] D. Raben, B. Helfrich, D. C. Chan, et al., "The effects of cetuximab alone and in combination with radiation and/or 
chemotherapy in lung cancer," Clinical Cancer Research, vol. 11, no. 2, pp. 795-805, 2005.

[92] S. Kim, C. N. Prichard, M. N. Younes, et al., "Cetuximab and irinotecan interact synergistically to inhibit the growth of orthotopic anaplastic thyroid carcinoma xenografts in nude mice," Clinical Cancer Research, vol. 12, no. 2, pp. 600-607, 2006.

[93] J. L. Eller, S. L. Longo, D. J. Hicklin, et al., "Activity of antiepidermal growth factor receptor monoclonal antibody C225 against glioblastoma multiforme," Neurosurgery, vol. 51, no. 4, pp. 1005-1014, 2002.

[94] A. D. Jensen, M. W. Münter, H. Bischoff, et al., "Treatment of non-small cell lung cancer with intensity-modulated radiation therapy in combination with cetuximab: the NEAR protocol (NCT00115518)," BMC Cancer, vol. 6, article 122, 2006.

[95] C. Delbaldo, J.-Y. Pierga, V. Dieras, et al., "Pharmacokinetic profile of cetuximab (Erbitux ${ }^{\mathrm{TM}}$ alone and in combination with irinotecan in patients with advanced EGFR-positive adenocarcinoma," European Journal of Cancer, vol. 41, no. 12, pp. 1739-1745, 2005.

[96] R. J. Schilder, H. B. Pathak, A. E. Lokshin, et al., "Phase II trial of single agent cetuximab in patients with persistent or recurrent epithelial ovarian or primary peritoneal carcinoma with the potential for dose escalation to rash," Gynecologic Oncology, vol. 113, no. 1, pp. 21-27, 2009.

[97] A. A. Secord, J. A. Blessing, D. K. Armstrong, et al., "Phase II trial of cetuximab and carboplatin in relapsed platinumsensitive ovarian cancer and evaluation of epidermal growth factor receptor expression: a Gynecologic Oncology Group study," Gynecologic Oncology, vol. 108, pp. 493-499, 2008.

[98] J. Konner, R. J. Schilder, F. A. DeRosa, et al., "A phase II study of cetuximab/paclitaxel/carboplatin for the initial treatment of advanced-stage ovarian, primary peritoneal, or fallopian tube cancer," Gynecologic Oncology, vol. 110, no. 2, pp. 140$145,2008$.

[99] M. V. Seiden, H. A. Burris, U. Matulonis, et al., "A phase II trial of EMD72000 (matuzumab), a humanized anti-EGFR monoclonal antibody, in patients with platinum-resistant ovarian and primary peritoneal malignancies," Gynecologic Oncology, vol. 104, no. 3, pp. 727-731, 2007.

[100] K. T. Flaherty and M. S. Brose, "Her-2 targeted therapy: beyond breast cancer and trastuzumab," Current Oncology Reports, vol. 8, no. 2, pp. 90-95, 2006.

[101] M. A. Bookman, K. M. Darcy, D. Clarke-Pearson, R. A. Boothby, and I. R. Horowitz, "Evaluation of monoclonal humanized anti-HER2 antibody, trastuzumab, in patients with recurrent or refractory ovarian or primary peritoneal carcinoma with overexpression of HER2: a phase II trial of the Gynecologic Oncology Group," Journal of Clinical Oncology, vol. 21, no. 2, pp. 283-290, 2003.

[102] S. R. Young, W.-H. Liu, J.-A. Brock, and S. T. Smith, "ERBB2 and chromosome 17 centromere studies of ovarian cancer by fluorescence in situ hybridization," Genes Chromosomes and Cancer, vol. 16, no. 2, pp. 130-137, 1996.

[103] D. Glenn, F. Ueland, A. Bicher, et al., "A randomized phase II trial with gemcitabine with or without pertuzumab (rhuMAb 2C4) in platinum-resistant ovarian cancer (OC): preliminary safety data," Journal of Clinical Oncology, vol. 24, p. 13001, 2006.

[104] Y. Wang, J. Hailey, D. Williams, et al., "Inhibition of insulinlike growth factor-I receptor (IGF-IR) signaling and tumor cell growth by a fully human neutralizing anti-IGF-IR antibody," Molecular Cancer Therapeutics, vol. 4, no. 8, pp. 1214-1221, 2005.

[105] E. K. Maloney, J. L. McLaughlin, N. E. Dagdigian, et al., "An anti-insulin-like growth factor I receptor antibody that is a potent inhibitor of cancer cell proliferation," Cancer Research, vol. 63, no. 16, pp. 5073-5083, 2003.

[106] J. Singh, E. M. Dobrusin, D. W. Fry, T. Haske, A. Whitty, and D. J. McNamara, "Structure-based design of a potent, selective, and irreversible inhibitor of the catalytic domain of the erbB receptor subfamily of protein tyrosine kinases," Journal of Medicinal Chemistry, vol. 40, no. 7, pp. 1130-1135, 1997.

[107] J. D. Moyer, E. G. Barbacci, K. K. Iwata, et al., "Induction of apoptosis and cell cycle arrest by CP-358,774, an inhibitor of epidermal growth factor receptor tyrosine kinase," Cancer Research, vol. 57, no. 21, pp. 4838-4848, 1997.

[108] E. K. Rowinsky, "The erbB family: targets for therapeutic development against cancer and therapeutic strategies using monoclonal antibodies and tyrosine kinase inhibitors," Annual Review of Medicine, vol. 55, pp. 433-457, 2004.

[109] C. L. Arteaga, T. T. Ramsey, L. K. Shawver, and C. A. Guyer, "Unliganded epidermal growth factor receptor dimerization induced by direct interaction of quinazolines with the ATP binding site," The Journal of Biological Chemistry, vol. 272, no. 37, pp. 23247-23254, 1997.

[110] J. Albanell and P. Gascón, "Small molecules with EGFR-TK inhibitor activity," Current Drug Targets, vol. 6, no. 3, pp. 259-274, 2005.

[111] J. M. Sewell, K. G. Macleod, A. Ritchie, J. F. Smyth, and S. P. Langdon, "Targeting the EGF receptor in ovarian cancer with the tyrosine kinase inhibitor ZD 1839 ('Iressa')," British Journal of Cancer, vol. 86, no. 3, pp. 456-462, 2002.

[112] R. J. Schilder, M. W. Sill, X. Chen, et al., "Phase II study of gefitinib in patients with relapsed or persistent ovarian or primary peritoneal carcinoma and evaluation of epidermal growth factor receptor mutations and immunohistochemical expression: a Gynecologic Oncology Group Study," Clinical Cancer Research, vol. 11, no. 15, pp. 5539-5548, 2005.

[113] E. M. Posadas, M. S. Liel, V. Kwitkowski, et al., "A phase II and pharmacodynamic study of gefitinib in patients with refractory or recurrent epithelial ovarian cancer," Cancer, vol. 109, no. 7, pp. 1323-1330, 2007.

[114] D. B. Costa, S. Kobayashi, D. G. Tenen, and M. S. Huberman, "Pooled analysis of the prospective trials of gefitinib monotherapy for EGFR-mutant non-small cell lung cancers," Lung Cancer, vol. 58, no. 1, pp. 95-103, 2007.

[115] U. Wagner, A. du Bois, J. Pfisterer, et al., "Gefitinib in combination with tamoxifen in patients with ovarian cancer refractory or resistant to platinum-taxane based therapya phase II trial of the AGO Ovarian Cancer Study Group (AGO-OVAR 2.6)," Gynecologic Oncology, vol. 105, no. 1, pp. 132-137, 2007.

[116] A. N. Gordon, N. Finkler, R. P. Edwards, et al., "Efficacy and safety of erlotinib $\mathrm{HCl}$, an epidermal growth factor receptor (HER1/EGFR) tyrosine kinase inhibitor, in patients with advanced ovarian carcinoma: results from a phase II multicenter study," International Journal of Gynecological Cancer, vol. 15, no. 5, pp. 785-792, 2005.

[117] H. S. Nimeiri, A. M. Oza, R. J. Morgan, et al., "Efficacy and safety of bevacizumab plus erlotinib for patients with recurrent ovarian, primary peritoneal, and fallopian tube cancer: a trial of the Chicago, $\mathrm{PMH}$, and California Phase II Consortia," Gynecologic Oncology, vol. 110, no. 1, pp. 49-55, 2008. 
[118] P. A. Vasey, M. Gore, R. Wilson, et al., "A phase Ib trial of docetaxel, carboplatin and erlotinib in ovarian, fallopian tube and primary peritoneal cancers," British Journal of Cancer, vol. 98, no. 11, pp. 1774-1780, 2008.

[119] M. W. Saif, A. Elfiky, and R. R. Salem, "Gastrointestinal perforation due to bevacizumab in colorectal cancer," Annals of Surgical Oncology, vol. 14, no. 6, pp. 1860-1869, 2007.

[120] P. A. Vasey, G. C. Jayson, A. Gordon, et al., "Phase III randomized trial of docetaxel-carboplatin versus paclitaxelcarboplatin as first-line chemotherpy for ovarian carcinoma," Journal of the National Cancer Institute, vol. 96, no. 22, pp. 1682-1691, 2004.

[121] W. Xia, R. J. Mullin, B. R. Keith, et al., "Anti-tumor activity of GW572016: a dual tyrosine kinase inhibitor blocks EGF activation of EGFR/erbB2 and downstream Erk1/2 and AKT pathways," Oncogene, vol. 21, no. 41, pp. 6255-6263, 2002.

[122] K. J. Kimball, T. M. Numnum, T. O. Kirby, et al., "A phase I study of lapatinib in combination with carboplatin in women with platinum sensitive recurrent ovarian carcinoma," Gynecologic Oncology, vol. 111, no. 1, pp. 95-101, 2008.

[123] S. Campos, O. Hamid, M. V. Seiden, et al., "Multicenter, randomized phase II trial of oral CI-1033 for previously treated advanced ovarian cancer," Journal of Clinical Oncology, vol. 23, no. 24, pp. 5597-5604, 2005.

[124] D. Li, L. Ambrogio, T. Shimamura, et al., "BIBW2992, an irreversible EGFR/HER2 inhibitor highly effective in preclinical lung cancer models," Oncogene, vol. 27, no. 34, pp. 4702-4711, 2008.

[125] P. Traxler, P. R. Allegrini, R. Brandt, et al., "AEE788: a dual family epidermal growth factor receptor/ErbB2 and vascular endothelial growth factor receptor tyrosine kinase inhibitor with antitumor and antiangiogenic activity," Cancer Research, vol. 64, no. 14, pp. 4931-4941, 2004.

[126] S.-F. Huang, H.-P. Liu, L.-H. Li, et al., "High frequency of epidermal growth factor receptor mutations with complex patterns in non-small cell lung cancers related to gefitinib responsiveness in Taiwan," Clinical Cancer Research, vol. 10, no. 24, pp. 8195-8203, 2004.

[127] T. J. Lynch, D. W. Bell, R. Sordella, et al., "Activating mutations in the epidermal growth factor receptor underlying responsiveness of non-small-cell lung cancer to gefitinib," The New England Journal of Medicine, vol. 350, no. 21, pp. 2129-2139, 2004.

[128] J. G. Paez, P. A. Jänne, J. C. Lee, et al., "EGFR mutations in lung, cancer: correlation with clinical response to gefitinib therapy," Science, vol. 304, no. 5676, pp. 1497-1500, 2004.

[129] W. Pao, V. Miller, M. Zakowski, et al., "EGF receptor gene mutations are common in lung cancers from "never smokers" and are associated with sensitivity of tumors to gefitinib and erlotinib," Proceedings of the National Academy of Sciences of the United States of America, vol. 101, no. 36, pp. 13306-13311, 2004.

[130] L. Lacroix, P. Pautier, P. Duvillard, et al., "Response of ovarian carcinomas to gefitinib-carboplatin-paclitaxel combination is not associated with EGFR kinase domain somatic mutations," International Journal of Cancer, vol. 118, no. 4, pp. 1068-1069, 2006.

[131] S. Ramalingam, J. Forster, C. Naret, et al., "Dual inhibition of the epidermal growth factor receptor with cetuximab, an IgG1 monoclonal antibody, and gefitinib, a tyrosine kinase inhibitor, in patients with refractory non-small cell lung cancer (NSCLC): a phase I study," Journal of Thoracic Oncology, vol. 3, no. 3, pp. 258-264, 2008.
[132] L. Toschi and F. Cappuzzo, "Understanding the new genetics of responsiveness to epidermal growth factor receptor tyrosine kinase inhibitors," The Oncologist, vol. 12, no. 2, pp. 211220, 2007.

[133] F. Morgillo and H.-Y. Lee, "Resistance to epidermal growth factor receptor-targeted therapy," Drug Resistance Updates, vol. 8, no. 5, pp. 298-310, 2005.

[134] P. Duesberg, R. Li, R. Sachs, A. Fabarius, M. B. Upender, and R. Hehlmann, "Cancer drug resistance: the central role of the karyotype,” Drug Resistance Updates, vol. 10, no. 1-2, pp. 5158, 2007.

[135] J. A. Engelman and J. Settleman, "Acquired resistance to tyrosine kinase inhibitors during cancer therapy," Current Opinion in Genetics and Development, vol. 18, no. 1, pp. 7379, 2008.

[136] G. Tortora, R. Bianco, G. Daniele, et al., "Overcoming resistance to molecularly targeted anticancer therapies: rational drug combinations based on EGFR and MAPK inhibition for solid tumours and haematologic malignancies," Drug Resistance Updates, vol. 10, no. 3, pp. 81-100, 2007.

[137] I. Martinez-Lacaci, P. Garcia Morales, J. L. Soto, and M. Saceda, "Tumour cells resistance in cancer therapy," Clinical and Translational Oncology, vol. 9, no. 1, pp. 13-20, 2007.

[138] R. Bianco, V. Damiano, T. Gelardi, G. Daniele, F. Ciardiello, and G. Tortora, "Rational combination of targeted therapies as a strategy to overcome the mechanisms of resistance to inhibitors of EGFR signaling," Current Pharmaceutical Design, vol. 13, no. 33, pp. 3358-3367, 2007.

[139] F. Morgillo, M. A. Bareschino, R. Bianco, G. Tortora, and F. Ciardiello, "Primary and acquired resistance to anti-EGFR targeted drugs in cancer therapy," Differentiation, vol. 75, no. 9, pp. 788-799, 2007.

[140] Z. Weihua, R. Tsan, W.-C. Huang, et al., "Survival of cancer cells is maintained by EGFR independent of its kinase activity," Cancer Cell, vol. 13, no. 5, pp. 385-393, 2008.

[141] R. A. Gatenby and R. J. Gillies, "Why do cancers have high aerobic glycolysis?" Nature Reviews Cancer, vol. 4, no. 11, pp. 891-899, 2004.

[142] K. Krysan, J. M. Lee, M. Dohadwala, et al., "Inflammation, epithelial to mesenchymal transition, and epidermal growth factor receptor tyrosine kinase inhibitor resistance," Journal of Thoracic Oncology, vol. 3, no. 2, pp. 107-110, 2008.

[143] M. P. Morelli, T. Cascone, T. Troiani, et al., "Sequencedependent antiproliferative effects of cytotoxic drugs and epidermal growth factor receptor inhibitors," Annals of Oncology, vol. 16, supplement 4, pp. iv61-iv68, 2005.

[144] B. J. B. Simpson, J. Weatherill, E. P. Miller, A. M. Lessells, S. P. Langdon, and W. R. Miller, "c-erbB-3 protein expression in ovarian tumours," British Journal of Cancer, vol. 71, no. 4, pp. 758-762, 1995.

[145] B. Tanner, D. Hasenclever, K. Stern, et al., "ErbB-3 predicts survival in ovarian cancer," Journal of Clinical Oncology, vol. 24, no. 26, pp. 4317-4323, 2006.

[146] A. C. Hsieh and M. M. Moasser, "Targeting HER proteins in cancer therapy and the role of the non-target HER3," British Journal of Cancer, vol. 97, no. 4, pp. 453-457, 2007.

[147] J. G. Christensen, R. E. Schreck, E. Chan, et al., "High levels of HER-2 expression alter the ability of epidermal growth factor receptor (EGFR) family tyrosine kinase inhibitors to inhibit EGFR phosphorylation in vivo," Clinical Cancer Research, vol. 7, no. 12, pp. 4230-4238, 2001. 
[148] N. V. Sergina, M. Rausch, D. Wang, et al., "Escape from HER-family tyrosine kinase inhibitor therapy by the kinaseinactive HER3," Nature, vol. 445, no. 7126, pp. 437-441, 2007.

[149] Q.-B. She, D. Solit, A. Basso, and M. M. Moasser, "Resistance to gefitinib in PTEN-Null HER-overexpressing tumor cells can be overcome through restoration of PTEN function or pharmacologic modulation of constitutive phosphatidylinositol 3'-kinase/Akt pathway signaling," Clinical Cancer Research, vol. 9, no. 12, pp. 4340-4346, 2003.

[150] R. Bianco, I. Shin, C. A. Ritter, et al., "Loss of PTEN/MMAC1/TEP in EGF receptor-expressing tumor cells counteracts the antitumor action of EGFR tyrosine kinase inhibitors," Oncogene, vol. 22, no. 18, pp. 2812-2822, 2003.

[151] E. Massarelli, M. Varella-Garcia, X. Tang, et al., "KRAS mutation is an important predictor of resistance to therapy with epidermal growth factor receptor tyrosine kinase inhibitors in non-small cell lung cancer," Clinical Cancer Research, vol. 13, no. 10, pp. 2890-2896, 2007.

[152] A. Lievre, J.-B. Bachet, D. Le Corre, et al., "KRAS mutation status is predictive of response to cetuximab therapy in colorectal cancer," Cancer Research, vol. 66, no. 8, pp. 3992 3995, 2006.

[153] V. A. Miller, G. J. Riely, M. F. Zakowski, et al., "Molecular characteristics of bronchioloalveolar carcinoma and adenocarcinoma, bronchioloalveolar carcinoma subtype, predict response to erlotinib," Journal of Clinical Oncology, vol. 26, no. 9, pp. 1472-1478, 2008.

[154] V. Auner, G. Kriegshäuser, D. Tong, et al., "KRAS mutation analysis in ovarian samples using a high sensitivity biochip assay," BMC Cancer, vol. 9, article 111, 2009.

[155] M. Liu, M. S. Bryant, J. Chen, et al., "Antitumor activity of SCH 66336, an orally bioavailable tricyclic inhibitor of farnesyl protein transferase, in human tumor xenograft models and wap-ras transgenic mice," Cancer Research, vol. 58, no. 21, pp. 4947-4956, 1998.

[156] C. Desbois-Mouthon, W. Cacheux, M.-J. Blivet-Van Eggelpoel, et al., "Impact of IGF-1R/EGFR cross-talks on hepatoma cell sensitivity to gefitinib," International Journal of Cancer, vol. 119, no. 11, pp. 2557-2566, 2006.

[157] R. Nahta, L. X. H. Yuan, Y. Du, and F. J. Esteva, "Lapatinib induces apoptosis in trastuzumab-resistant breast cancer cells: effects on insulin-like growth factor I signaling," Molecular Cancer Therapeutics, vol. 6, no. 2, pp. 667-674, 2007.

[158] S. M. Thomas, N. E. Bhola, Q. Zhang, et al., "Cross-talk between $\mathrm{G}$ protein-coupled receptor and epidermal growth factor receptor signaling pathways contributes to growth and invasion of head and neck squamous cell carcinoma," Cancer Research, vol. 66, no. 24, pp. 11831-11839, 2006.

[159] Q. Zhang, N. E. Bhola, V. W. Y. Lui, et al., "Antitumor mechanisms of combined gastrin-releasing peptide receptor and epidermal growth factor receptor targeting in head and neck cancer," Molecular Cancer Therapeutics, vol. 6, no. 4, pp. 1414-1424, 2007.

[160] J. A. Engelman, K. Zejnullahu, T. Mitsudomi, et al., "MET amplification leads to gefitinib resistance in lung cancer by activating ERBB3 signaling," Science, vol. 316, no. 5827, pp. 1039-1043, 2007.

[161] S. N. Holden, S. G. Eckhardt, R. Basser, et al., "Clinical evaluation of ZD6474, an orally active inhibitor of VEGF and EGF receptor signaling, in patients with solid, malignant tumors," Annals of Oncology, vol. 16, no. 8, pp. 1391-1397, 2005.

[162] S. Skvortsov, B. Sarg, J. Loeffler-Ragg, et al., "Different proteome pattern of epidermal growth factor receptorpositive colorectal cancer cell lines that are responsive and nonresponsive to C225 antibody treatment," Molecular Cancer Therapeutics, vol. 3, no. 12, pp. 1551-1558, 2004.

[163] S. Nelander, W. Wang, B. Nilsson, et al., "Models from experiments: combinatorial drug perturbations of cancer cells," Molecular Systems Biology, vol. 4, article 216, 2008.

[164] W. Kassouf, C. P. N. Dinney, G. Brown, et al., "Uncoupling between epidermal growth factor receptor and downstream signals defines resistance to the antiproliferative effect of gefitinib in bladder cancer cells," Cancer Research, vol. 65, no. 22, pp. 10524-10535, 2005.

[165] K. Wang, L. Gan, E. Jeffery, et al., "Monitoring gene expression profile changes in ovarian carcinomas using cDNA microarray," Gene, vol. 229, no. 1-2, pp. 101-108, 1999.

[166] M. E. Schaner, D. T. Ross, G. Ciaravino, et al., "Gene expression patterns in ovarian carcinomas," Molecular Biology of the Cell, vol. 14, no. 11, pp. 4376-4386, 2003.

[167] Z. E. Selvanayagam, T. H. Cheung, N. Wei, et al., "Prediction of chemotherapeutic response in ovarian cancer with DNA microarray expression profiling," Cancer Genetics and Cytogenetics, vol. 154, no. 1, pp. 63-66, 2004.

[168] C. M. Coticchia, J. Yang, and M. A. Moses, "Ovarian cancer biomarkers: current options and future promise," Journal of the National Comprehensive Cancer Network, vol. 6, no. 8, pp. 795-802, 2008.

[169] R. I. Olivier, M. van Beurden, and L. J. van' t Veer, “The role of gene expression profiling in the clinical management of ovarian cancer," European Journal of Cancer, vol. 42, no. 17, pp. 2930-2938, 2006.

[170] U. McDermott, S. V. Sharma, and J. Settleman, "Highthroughput lung cancer cell line screening for genotypecorrelated sensitivity to an EGFR kinase inhibitor," Methods in Enzymology, vol. 438, pp. 331-341, 2008.

[171] D. Calzolari, S. Bruschi, L. Coquin, et al., "Search algorithms as a framework for the optimization of drug combinations," PLoS Computational Biology, vol. 4, no. 12, Article ID e1000249, 2008.

[172] J. Tapper, E. Kettunen, W. El-Rifai, M. Seppälä, L. C. Andersson, and S. Knuutila, "Changes in gene expression during progression of ovarian carcinoma," Cancer Genetics and Cytogenetics, vol. 128, no. 1, pp. 1-6, 2001.

[173] P. Schraml, G. Schwerdtfeger, F. Burkhalter, et al., "Combined array comparative genomic hybridization and tissue microarray analysis suggest PAK1 at 11q13.5-q14 as a critical oncogene target in ovarian carcinoma," American Journal of Pathology, vol. 163, no. 3, pp. 985-992, 2003.

[174] K. D. Steffensen, M. Waldstrøm, R. F. Andersen, et al., "Protein levels and gene expressions of the epidermal growth factor receptors, HER1,H ER2, HER3 and HER4 in benign and malignant ovarian tumors," International Journal of Oncology, vol. 33, no. 1, pp. 195-204, 2008.

[175] Ö. Alper, E. S. Bergmann-Leitner, T. A. Bennett, N. F. Hacker, K. Stromberg, and W. G. Stetler-Stevenson, "Epidermal growth factor receptor signalling and the invasive phenotype of ovarian carcinoma cells," Journal of the National Cancer Institute, vol. 93, no. 18, pp. 1375-1384, 2001.

[176] Z. Guo, S. Cai, R. Fang, et al., "The synergistic effects of CXCR4 and EGFR on promoting EGF-mediated metastasis 
in ovarian cancer cells," Colloids and Surfaces B, vol. 60, no. 1, pp. 1-6, 2007.

[177] K. R. Kalli, S. V. Bradley, S. Fuchshuber, and C. A. Conover, "Estrogen receptor-positive human epithelial ovarian carcinoma cells respond to the antitumor drug suramin with increased proliferation: possible insight into ER and epidermal growth factor signaling interactions in ovarian cancer," Gynecologic Oncology, vol. 94, no. 3, pp. 705-712, 2004.

[178] J. Morrison, S. S. Briggs, N. Green, et al., "Virotherapy of ovarian cancer with polymer-cloaked adenovirus retargeted to the epidermal growth factor receptor," Molecular Therapy, vol. 16, no. 2, pp. 244-251, 2008.

[179] P. A. van Dam, I. B. Vergote, D. G. Lowe, et al., "Expression of c-erbB-2, c-myc, and c-ras oncoproteins, insulin-like growth factor receptor I, and epidermal growth factor receptor in ovarian carcinoma," Journal of Clinical Pathology, vol. 47, no. 10, pp. 914-919, 1994.

[180] K. D. Cowden Dahl, J. Symowicz, Y. Ning, et al., "Matrix metalloproteinase 9 is a mediator of epidermal growth factordependent E-cadherin loss in ovarian carcinoma cells," Cancer Research, vol. 68, no. 12, pp. 4606-4613, 2008.

[181] C. Cao, S. Lu, A. Sowa, et al., "Priming with EGFR tyrosine kinase inhibitor and EGF sensitizes ovarian cancer cells to respond to chemotherapeutical drugs," Cancer Letters, vol. 266, no. 2, pp. 249-262, 2008.

[182] N. G. Cloven, A. Kyshtoobayeva, R. A. Burger, I.-R. Yu, and J. P. Fruehauf, "In vitro chemoresistance and biomarker profiles are unique for histologic subtypes of epithelial ovarian cancer," Gynecologic Oncology, vol. 92, no. 1, pp. 160166, 2004.

[183] C. Schindlbeck, P. Hantschmann, M. Zerzer, et al., "Prognostic impact of KI67, p53, human epithelial growth factor receptor 2, topoisomerase II $\alpha$, epidermal growth factor receptor, and nm23 expression of ovarian carcinomas and disseminated tumor cells in the bone marrow," International Journal of Gynecological Cancer, vol. 17, no. 5, pp. 1047-1055, 2007.

[184] I. Skirnisdottir, T. Seidal, and B. Sorbe, "A new prognostic model comprising p53, EGFR, and tumor grade in early stage epithelial ovarian carcinoma and avoiding the problem of inaccurate surgical staging," International Journal of Gynecological Cancer, vol. 14, no. 2, pp. 259-270, 2004.

[185] Z. Suo, K. Karbove, C. G. Trope, K. Metodiev, and J. M. Nesland, "Papillary serous carcinoma of the ovary: an ultrastructural and immunohistochemical study," Ultrastructural Pathology, vol. 28, no. 3, pp. 141-147, 2004.

[186] Ö. Alper, M. L. De Santis, K. Stromberg, N. F. Hacker, Y. S. Cho-Chung, and D. S. Salomon, "Anti-sense suppression of epidermal growth factor receptor expression alters cellular proliferation, cell-adhesion and tumorigenicity in ovarian cancer cells," International Journal of Cancer, vol. 88, no. 4, pp. 566-574, 2000.

[187] P. de Graeff, A. P. G. Crijns, K. A. Ten Hoor, et al., "The ErbB signalling pathway: protein expression and prognostic value in epithelial ovarian cancer," British Journal of Cancer, vol. 99, no. 2, pp. 341-349, 2008.

[188] C. Facco, S. La Rosa, A. Dionigi, S. Uccella, C. Riva, and C. Capella, "High expression of growth factors and growth factor receptors in ovarian metastases from ileal carcinoids: an immunohistochemical study of 2 cases," Archives of Pathology and Laboratory Medicine, vol. 122, no. 9, pp. 828832, 1998.
[189] G. Ferrandina, F. O. Ranelletti, L. Lauriola, et al., "Cyclooxygenase-2 (COX-2), epidermal growth factor receptor (EGFR), and Her-2/neu expression in ovarian cancer," Gynecologic Oncology, vol. 85, no. 2, pp. 305-310, 2002.

[190] B. A. Goff, J. A. Ries, L. P. Els, M. D. Coltrera, and A. M. Gown, "Immunophenotype of ovarian cancer as predictor of clinical outcome: evaluation at primary surgery and secondlook procedure," Gynecologic Oncology, vol. 70, no. 3, pp. 378-385, 1998.

[191] A. Harlozinska, J. K. Bar, E. Sobanska, and M. Goluda, "Epidermal growth factor receptor and c-erbB-2 oncoproteins in tissue and tumor effusion cells of histopathologically different ovarian neoplasms," Tumor Biology, vol. 19, no. 5, pp. 364-373, 1998.

[192] Y. Kuwashima, T. Uehara, K. Kishi, K. Shiromizu, M. Matsuzawa, and S. Takayama, "Immunohistochemical characterization of undifferentiated carcinomas of the ovary," Journal of Cancer Research and Clinical Oncology, vol. 120, no. 11, pp. 672-677, 1994.

[193] M. Mandai, I. Konishi, M. Koshiyama, et al., "Expression of metastasis-related $\mathrm{nm} 23-\mathrm{H} 1$ and $\mathrm{nm} 23-\mathrm{H} 2$ genes in ovarian carcinomas: correlation with clinicopathology, EGFR, cerbB-2, and c-erbB-3 genes, and sex steroid receptor expression," Cancer Research, vol. 54, no. 7, pp. 1825-1830, 1994.

[194] I. Skirnisdottir, B. Sorbe, and T. Seidal, "The growth factor receptors HER-2/neu and EGFR, their relationship, and their effects on the prognosis in early stage (FIGO I-II) epithelial ovarian carcinoma," International Journal of Gynecological Cancer, vol. 11, no. 2, pp. 119-129, 2001.

[195] C. van Haaften-Day, P. Russell, C. M. Boyer, et al., "Expression of cell regulatory proteins in ovarian borderline tumors," Cancer, vol. 77, no. 10, pp. 2092-2098, 1996.

[196] M. Aponte, W. Jiang, M. Lakkis, et al., "Activation of plateletactivating factor receptor and pleiotropic effects on tyrosine phospho-EGFR/Src/FAK/paxillin in ovarian cancer," Cancer Research, vol. 68, no. 14, pp. 5839-5848, 2008.

[197] B. Nolen, A. Marrangoni, L. Velikokhatnaya, et al., "A serum based analysis of ovarian epithelial tumorigenesis," Gynecologic Oncology, vol. 112, no. 1, pp. 47-54, 2009.

[198] J. K. Chan, H. Pham, X. J. You, et al., "Suppression of ovarian cancer cell tumorigenicity and evasion of cisplatin resistance using a truncated epidermal growth factor receptor in a rat model," Cancer Research, vol. 65, no. 8, pp. 3243-3248, 2005.

[199] G. Ferrandina, G. Scambia, P. Benedetti Panici, et al., "Effects of dexamethasone on the growth and epidermal growth factor receptor expression of the OVCA 433 ovarian cancer cells," Molecular and Cellular Endocrinology, vol. 83, no. 2-3, pp. 183-193, 1992.

[200] S. L. Bull Phelps, J. O. Schorge, M. J. Peyton, et al., "Implications of EGFR inhibition in ovarian cancer cell proliferation," Gynecologic Oncology, vol. 109, no. 3, pp. 411417, 2008.

[201] T. Servidei, A. Riccardi, S. Mozzetti, C. Ferlini, and R. Riccardi, "Chemoresistant tumor cell lines display altered epidermal growth factor receptor and HER3 signaling and enhanced sensitivity to gefitinib," International Journal of Cancer, vol. 123, no. 12, pp. 2939-2949, 2008.

[202] B. Davidson, V. Espina, S. M. Steinberg, et al., "Proteomic analysis of malignant ovarian cancer effusions as a tool for biologic and prognostic profiling," Clinical Cancer Research, vol. 12, no. 3, pp. 791-799, 2006.

[203] E. M. Posadas, V. Kwitkowski, H. L. Kotz, et al., "A prospective analysis of imatinib-induced c-KIT modulation in ovarian 
cancer: a phase II clinical study with proteomic profiling," Cancer, vol. 110, no. 2, pp. 309-317, 2007.

[204] J.-H. Choi, K.-C. Choi, N. Auersperg, and P. C. K. Leung, "Gonadotropins upregulate the epidermal growth factor receptor through activation of mitogen-activated protein kinases and phosphatidyl-inositol-3-kinase in human ovarian surface epithelial cells," Endocrine-Related Cancer, vol. 12, no. 2, pp. 407-421, 2005.

[205] C. Ji, C. Cao, S. Lu, et al., "Curcumin attenuates EGF-induced AQP3 up-regulation and cell migration in human ovarian cancer cells," Cancer Chemotherapy and Pharmacology, vol. 62, no. 5, pp. 857-865, 2008.

[206] A. J. Li, D. R. Scoles, K. U. M. Armstrong, and B. Y. Karlan, "Androgen receptor cytosine-adenine-guanine repeat polymorphisms modulate EGFR signaling in epithelial ovarian carcinomas," Gynecologic Oncology, vol. 109, no. 2, pp. 220225,2008 .

[207] C. Porcile, A. Bajetto, F. Barbieri, et al., "Stromal cell-derived factor- $1 \alpha$ (SDF-1 $\alpha /$ CXCL12) stimulates ovarian cancer cell growth through the EGF receptor transactivation," Experimental Cell Research, vol. 308, no. 2, pp. 241-253, 2005.

[208] K. Selvendiran, A. Bratasz, L. Tong, L. J. Ignarro, and P. Kuppusamy, "NCX-4016, a nitro-derivative of aspirin, inhibits EGFR and STAT3 signaling and modulates Bcl-2 proteins in cisplatin-resistant human ovarian cancer cells and xenografts," Cell Cycle, vol. 7, no. 1, pp. 81-88, 2008.

[209] C. Zhou, L. Qiu, Y. Sun, et al., "Inhibition of EGFR/ PI3K/AKT cell survival pathway promotes TSA's effect on cell death and migration in human ovarian cancer cells," International Journal of Oncology, vol. 29, no. 1, pp. 269-278, 2006.

[210] S. D. Pack, Ö. Alper, K. Stromberg, et al., "Simultaneous suppression of epidermal growth factor receptor and c-erbB2 reverses aneuploidy and malignant phenotype of a human ovarian carcinoma cell line," Cancer Research, vol. 64, no. 3, pp. 789-794, 2004.

[211] X. Zhang, M.-T. Ling, H. Feng, Y. C. Wong, S. W. Tsao, and X. Wang, "Id-1 stimulates cell proliferation through activation of EGFR in ovarian cancer cells," British Journal of Cancer, vol. 91, no. 12, pp. 2042-2047, 2004.

[212] J. V. Ilekis, J. P. Connor, G. S. Prins, K. Ferrer, C. Niederberger, and B. Scoccia, "Expression of epidermal growth factor and androgen receptors in ovarian cancer," Gynecologic Oncology, vol. 66, no. 2, pp. 250-254, 1997.

[213] M. G. del Carmen, I. Rizvi, Y. Chang, et al., "Synergism of epidermal growth factor receptor-targeted immunotherapy with photodynamic treatment of ovarian cancer in vivo," Journal of the National Cancer Institute, vol. 97, no. 20, pp. 1516-1524, 2005.

[214] A. A. Kamat, T. J. Kim, C. N. Landen Jr., et al., "Metronomic chemotherapy enhances the efficacy of antivascular therapy in ovarian cancer," Cancer Research, vol. 67, no. 1, pp. 281$288,2007$.

[215] S. Miyamoto, M. Hirata, A. Yamazaki, et al., "Heparinbinding EGF-like growth factor is a promising target for ovarian cancer therapy," Cancer Research, vol. 64, no. 16, pp. 5720-5727, 2004.

[216] G. W. Rewcastle, D. K. Murray, W. L. Elliott, et al., "Tyrosine kinase inhibitors. 14. Structure-activity relationships for methyl-amino-substituted derivatives of 4-[3bromophenyl)amino]-6-(methylaminø)-pyrido[3,4-d] pyrimidine (PD 158780), a potent and specific inhibitor of the tyrosine kinase activity of receptors for the EGF family of growth factors," Journal of Medicinal Chemistry, vol. 41, no. 5, pp. 742-751, 1998.

[217] L. Rosano, V. Di Castro, F. Spinella, et al., "Combined targeting of endothelin a receptor and epidermal growth factor receptor in ovarian cancer shows enhanced antitumor activity," Cancer Research, vol. 67, no. 13, pp. 6351-6359, 2007.

[218] P. W. Vincent, A. J. Bridges, D. J. Dykes, et al., "Anticancer efficacy of the irreversible EGFr tyrosine kinase inhibitor PD 0169414 against human tumor xenografts," Cancer Chemotherapy and Pharmacology, vol. 45, no. 3, pp. 231-238, 2000.

[219] S. R. Wedge, D. J. Ogilvie, M. Dukes, et al., “ZD6474 inhibits vascular endothelial growth factor signaling, angiogenesis, and tumor growth following oral administration," Cancer Research, vol. 62, no. 16, pp. 4645-4655, 2002. 


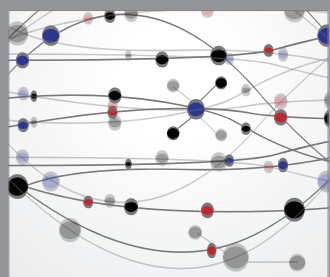

The Scientific World Journal
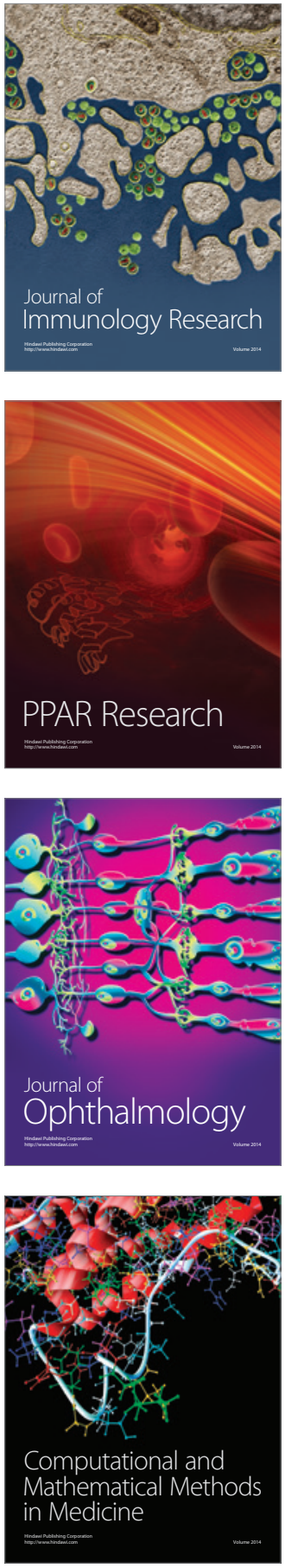

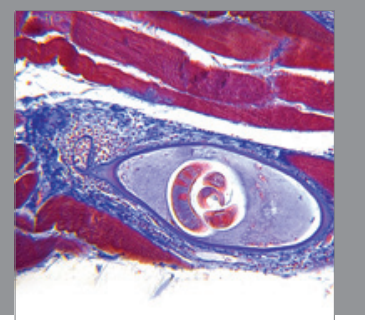

Gastroenterology

Research and Practice
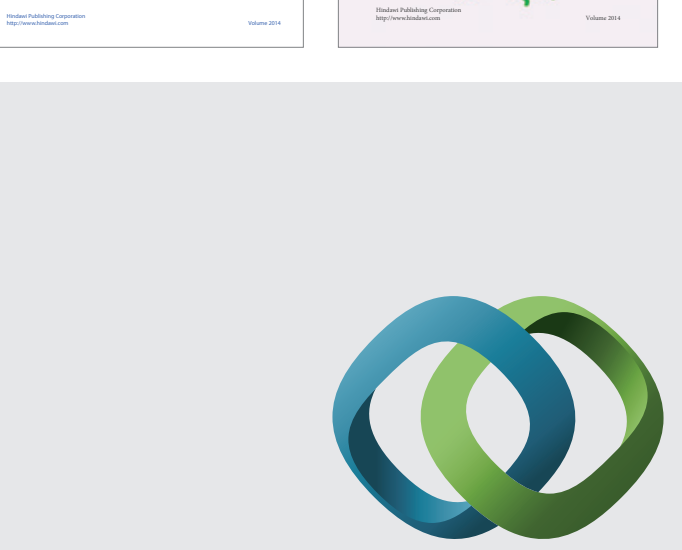

\section{Hindawi}

Submit your manuscripts at

http://www.hindawi.com
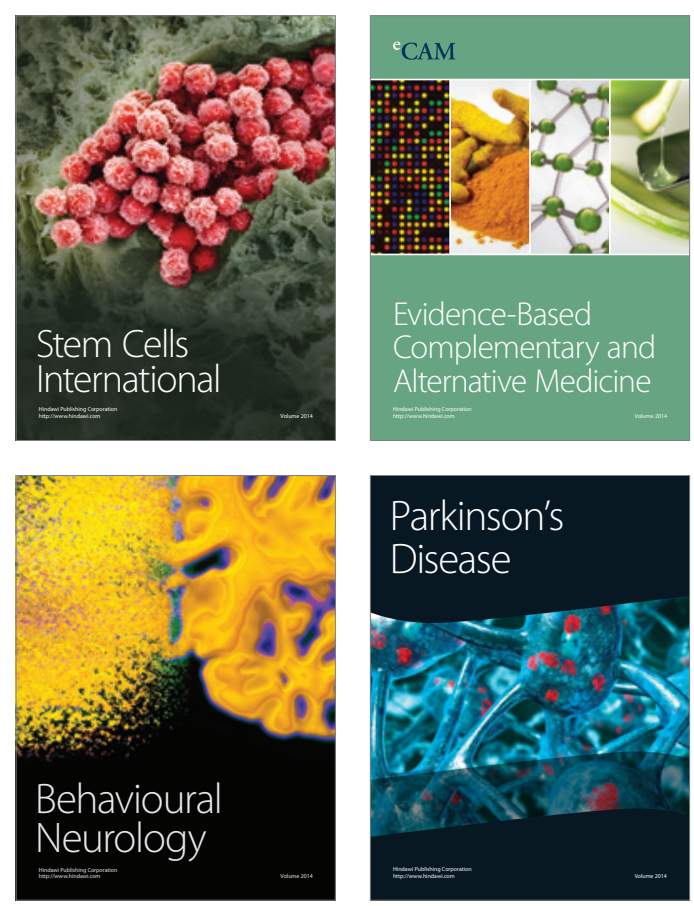

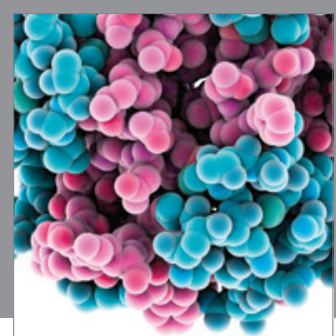

Journal of
Diabetes Research

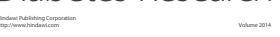

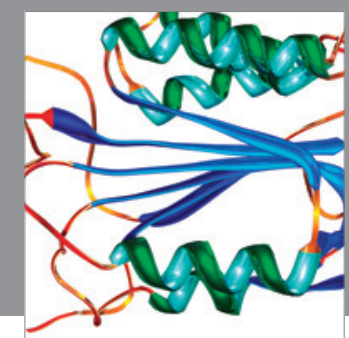

Disease Markers
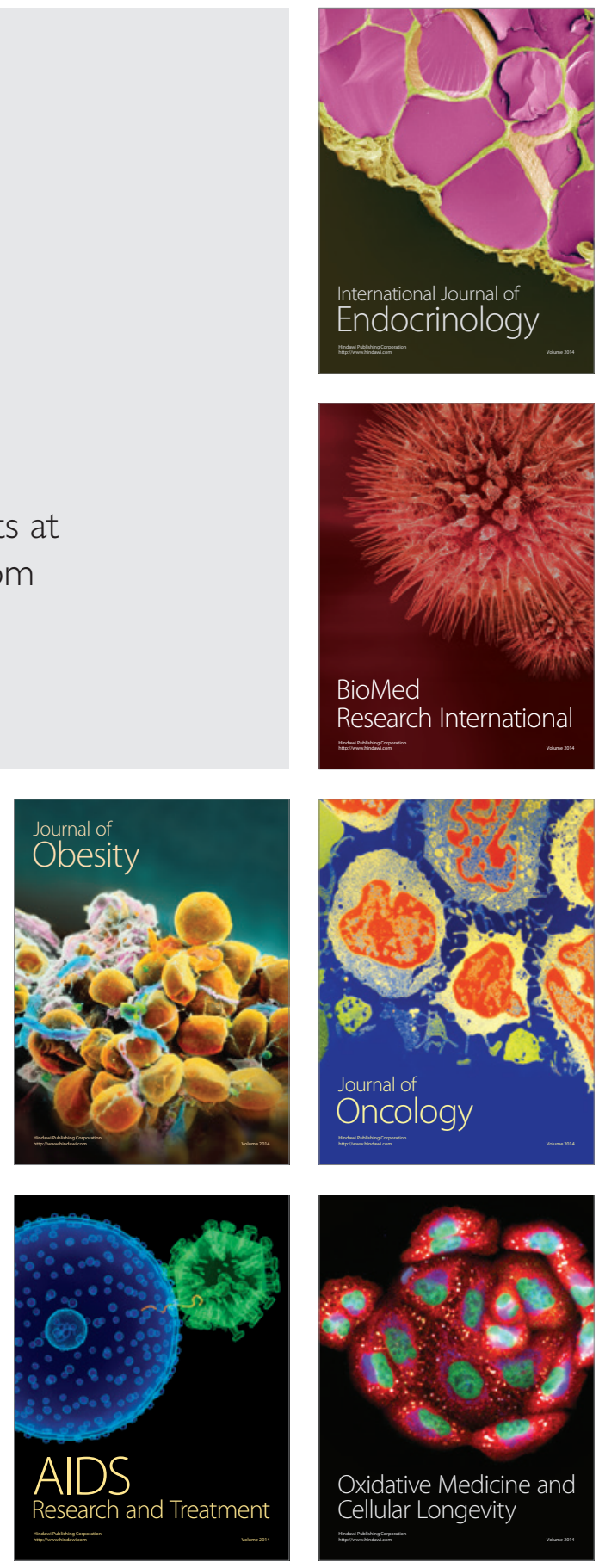